\title{
Sinking rates and ballast composition of particles in the Atlantic Ocean: implications for the organic carbon fluxes to the deep ocean
}

\author{
G. Fischer ${ }^{1}$ and G. Karakaş ${ }^{2}$ \\ ${ }^{1}$ Faculty of Geosciences and MARUM, University of Bremen, Klagenfurter and Leobener Strasse, 28359 Bremen, Germany \\ ${ }^{2}$ Alfred-Wegener-Institute for Polar and Marine Research, Columbusstrasse, 27568 Bremerhaven, Germany
}

Received: 29 February 2008 - Published in Biogeosciences Discuss.: 16 June 2008

Revised: 3 December 2008 - Accepted: 3 December 2008 - Published: 16 January 2009

\begin{abstract}
The flux of materials to the deep sea is dominated by larger, organic-rich particles with sinking rates varying between a few meters and several hundred meters per day. Mineral ballast may regulate the transfer of organic matter and other components by determining the sinking rates, e.g. via particle density. We calculated particle sinking rates from mass flux patterns and alkenone measurements applying the results of sediment trap experiments from the Atlantic Ocean. We have indication for higher particle sinking rates in carbonate-dominated production systems when considering both regional and seasonal data. During a summer coccolithophorid bloom in the Cape Blanc coastal upwelling off Mauritania, particle sinking rates reached almost $570 \mathrm{~m}$ per day, most probably due the fast sedimentation of densely packed zooplankton fecal pellets, which transport high amounts of organic carbon associated with coccoliths to the deep ocean despite rather low production. During the recurring winter-spring blooms off NW Africa and in opalrich production systems of the Southern Ocean, sinking rates of larger particles, most probably diatom aggregates, showed a tendency to lower values. However, there is no straightforward relationship between carbonate content and particle sinking rates. This could be due to the unknown composition of carbonate and/or the influence of particle size and shape on sinking rates. It also remains noticeable that the highest sinking rates occurred in dust-rich ocean regions off NW Africa, but this issue deserves further detailed field and laboratory investigations. We obtained increasing sinking rates with depth. By using a seven-compartment biogeochemical model, it was shown that the deep ocean organic carbon flux at a mesotrophic sediment trap site off Cape Blanc can be captured fairly well using seasonal variable particle sinking rates. Our model provides a total organic carbon flux of
\end{abstract}

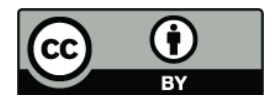

Correspondence to: G. Fischer (gerhard.fischer@uni-bremen.de)
$0.29 \mathrm{Tg}$ per year down to $3000 \mathrm{~m}$ off the NW African upwelling region between 5 and $35^{\circ} \mathrm{N}$. Simple parameterisations of remineralisation and sinking rates in such models, however, limit their capability in reproducing the flux variation in the water column.

\section{Introduction}

The biological pump plays a critical role in the discussion about glacial-interglacial $p \mathrm{CO}_{2}$ variations measured in ice cores as well as in the evaluation of future climate scenarios. At highest efficiency, it may strongly draw down atmospheric $p \mathrm{CO}_{2}$, at lowest efficiency, in a biologically dead ocean, the value may significantly exceed modern atmospheric values (Broecker, 1982). The transfer of particulate organic carbon to depth in modern oceans shows considerable regional and temporal variability in the fraction of primary production ( $\sim 2$ to $50 \%$ ) being exported to depth. Despite considerable progress in recent years, this variability is far from being completely understood, mainly due to a lack of knowledge of relevant meso- and bathypelagic processes (e.g. Boyd and Trull, 2007).

The efficiency of carbon transfer to depth is influenced by three major processes (de la Rocha and Passow, 2007): a) the amount of primary production in the photic zone, b) the sinking rate of organic carbon, and c) the rate of POC decomposition. All these processes impact on ocean biogeochemistry. The detritus of small zoo- and phytoplankton sinks predominantly as larger composite particles, mainly fecal pellets or marine snow aggregates (Alldredge and Silver, 1988). These particles are widely considered to be major transport vehicles of materials to the deep sea (e.g. Smetacek, 1985; Pilskaln and Honjo, 1987). However, sinking rates of both particle types display a large variation which cannot be explained yet. Direct field measurements are still rare and many values originated from laboratory experiments (e.g. Ploug et al., 2008a),

Published by Copernicus Publications on behalf of the European Geosciences Union. 
coastal-near regions or from surface waters only (Alldredge and Silver, 1988; Angel, 1984). Particle sinking rates may contribute to variable organic carbon flux attenuation curves in the water column (e.g. Francois et al., 2002; Boyd and Trull, 2007). Increasing sinking rates with depth provide indirect evidence of changes in particle porosity and/or density in the water column, probably linked to particle composition (Berelson, 2002).

Mineral ballasting is an important issue in the discussion about particle formation, sinking rates and carbon transfer to the deep ocean (Ittekkot, 1993; Armstrong et al., 2002; Francois et al., 2002; Klaas and Archer, 2002; Passow, 2004; De La Rocha and Passow, 2007; Thunell et al., 2007). However, little is known about the mechanisms behind the ballast theory and empirical findings do not show cause and effect (Passow, 2004). The use of global relationships to derive global algorithms, without looking in detail at spatial and temporal variations has also been questioned (e.g. Ragueneau et al., 2006). Passow (2004) suggested that the POC flux determines the flux of ballast minerals and that marine snow aggregates scavenge mineral particles, both of biogenic and lithogenic origin until they reach their carrying capacity. Armstrong et al. (2002) argued that one fraction of POC reaching the deep ocean is chemically protected from degradation by mineral particles, which is debated by Ploug et al. (2008a). Differential sinking speeds of larger particles could also explain field observations and the ballast theory (Klaas and Archer, 2002; Francois et al., 2002). The latter authors speculated that remineralisation in the twilight zone of the low-latitude oceans is relatively low due to high carbonate mineral availability which might constitute dense and fast sinking fecal pellets. Fecal pellets may be the major carrier for coccolithophorids to the deep ocean (de La Rocha and Passow, 2007). In contrast, high-latitude oceans with high export of marine snow aggregates which are formed preferentially by diatoms and which have a more labile nature may be characterized by reduced particle sinking rates and low organic carbon transfer rates (Francois et al., 2002). Such scenarios would correspond to the overall picture that fecal pellets have generally higher sinking rates ( 10-2700 $\mathrm{m} \mathrm{d}^{-1}$, Angel, 1984, 1989; Bruland and Silver, 1981; Turner, 2002) than the less dense and TEP-rich marine snow aggregates (1-368 $\mathrm{m} \mathrm{d}^{-1}$; Alldredge and Silver, 1988) which may even be retained in the surface layer for several days (Riebesell, 1992). However, retention of organic matter in the surface layer due to the production of copepod fecal pellets followed by coprophagy may also be observed (e.g. Bathmann et al., 1987; Lampitt et al., 1990). There is also evidence that diatoms may sink rapidly to the seafloor in the form of larger chains, e.g. at the Antartic Polar Front (Dubischar and Bathmann, 2002). Both findings disagree with the suggestions of Francois et al. (2002) which were derived from a global flux data set.
The role of lithogenic material, i.e. dust as a major carrier for organic carbon is discussed controversially (e.g. Boyd and Trull, 2007). Globally, the role may be irrelevant as pointed out by Francois et al. (2002). Locally, e.g. off NW Africa, the role of dust as ballast should be considered. However, laboratory experiments have shown that lithogenic material could even decrease the downward flux of phytoplankton biomass (Hamm, 2002). According to Berelson (2002), particle sinking rates estimated from sediment trap studies are not controlled by the lithogenic contents of particles. He concluded that sinking velocities of particles increase with depth, but the database applied in this study was not from the same locations.

The variation in particle characteristics across different production systems is an issue that biogeochemical models have to address. A bigger challenge for modellers is the representation of particle transformations in the water column as they sink. Biogeochemical models (e.g. Gruber et al., 2006) have traditionally prescribed particle sinking velocities that are at least several orders of magnitude smaller than the velocities estimated from deep water sediment trap recordings. This inconsistency must be taken care of by appropriate algorithms, which ensure reconciliation of surface ocean productivity with deep water flux. Coagulation theory attempted to formulate particle aggregation and disaggregation and achieved significant progress in explaining these transformations in the water column (see Jackson, 2005 for a review). In a rare application, Gehlen et al. (2006) implemented an aggregation kernel into a 3-D biogeochemical ocean model to study the biological soft tissue pump. They showed that an aggregation model did not improve subsurface POC flux relative to the simple, 2-particle-sizeclasses model with prescribed sinking rates, despite Jackson's (2001) scepticism about simple parameterisations to represent the effect of coagulation in biogeochemical models.

This study aims to better understand the regional and temporal variations in the efficiency of the biological pump in the Atlantic Ocean and off Mauritania by looking at the variability of particle sinking rates of various production systems in relation to particle composition. We examine the role of coccolithophorid carbonate as a major ballast mineral, not total carbonate (mainly coccolithophorids and planktonic foraminifera) as done by Francois et al. (2002) and Klaas and Archer (2002). We use alkenone-derived sea surface temperatures (SSTs, Müller and Fischer, 2001) to better assess coccolithophorid-associated sinking rates of particles in the meso- and bathypelagic. We will use particle flux records from different sediment trap levels to approximate particle sinking rates in the deeper water column and to test the hypothesis of increasing sinking rates with depth (Berelson, 2002). Collections of particles spanning several years also allow an assessment of the seasonal and interannual variability of particle sinking rates which has not been done so far. 
We then extend our investigation to explore the possibility of representing particle flux in the deep water by using a simple regional biogeochemical model with prescribed, averaged sinking velocities. We subsequently show how seasonal variation of particle sinking rates control deep water carbon flux. The model was setup for the Cape Blanc filament region in the NW African upwelling system, which hosts significant export production with some biogenic opal and high carbonate production. Because size spectrum and sinking speeds of particles can be simulated fairly well with two size classes (Gehlen et al., 2006), a biogeochemical model with two detritus compartments was used for modeling particle flux. The biogeochemical model was coupled to an ocean circulation model and was run with real-time forcing data for the measurement period. The results are compared to the satellitederived imagery and deep sediment trap recordings.

\section{Material and methods}

\subsection{Sediment trap collections and analysis}

Large-aperture time-series sediment traps of the Kiel-type were used for particle collection at our study sites (Fig. 1). They were equipped with 20 cups and an opening of $0.5 \mathrm{~m}^{2}$ (Kremling et al., 1996). Larger swimmers were removed by hand using foreceps and the material was wet-sieved through a $1 \mathrm{~mm}$ nylon mesh. Therefore, particle flux data from all sites refer to the size fraction $<1 \mathrm{~mm}$; material flux in the $>1 \mathrm{~mm}$ size fraction was mostly negligible. Larger marine snow aggregates $(>1 \mathrm{~mm})$ which could partly constitute mass flux but rapidly disintegrate in the sampling cups are therefore included. Mass flux has not been corrected for losses due to degradation and dissolution in the sampling cups. The homogenized samples were split into subsamples on which further analysis was performed. Mass flux was determined by weighing the sub-samples. Total carbon, organic carbon and nitrogen were obtained by combustion with a HEREAUS-CHN-analyzer. Organic carbon was measured after removal of carbonate with $2 \mathrm{~N} \mathrm{HCl}$. Carbonate was determined by subtracting organic carbon from total carbon, the latter being measured by combustion without a pretreatment with $2 \mathrm{~N} \mathrm{HCl}$. Biogenic opal was measured according to Müller and Schneider (1993) using a sequential leaching technique with $1 \mathrm{MNaOH}$ as dissolving agent. The lithogenic fraction was calculated as follows: Lithogenic $=$ Total flux - opal - carbonate $-2^{*} \mathrm{C}_{\text {org }}$. Alkenone concentrations and SST were calculated according to Müller and Fischer (2001).

To avoid severe problems with the trapping efficiency, which appears to be lower in the surface and subsurface waters (Yu et al., 2001; Scholten et al., 2001), we attempted to use flux data from deeper traps to circumvent strong undersampling (Buesseler et al., 2007). Some of our mass flux data derived from shallower depth $(\sim 500-1000 \mathrm{~m}$; Table 1) and

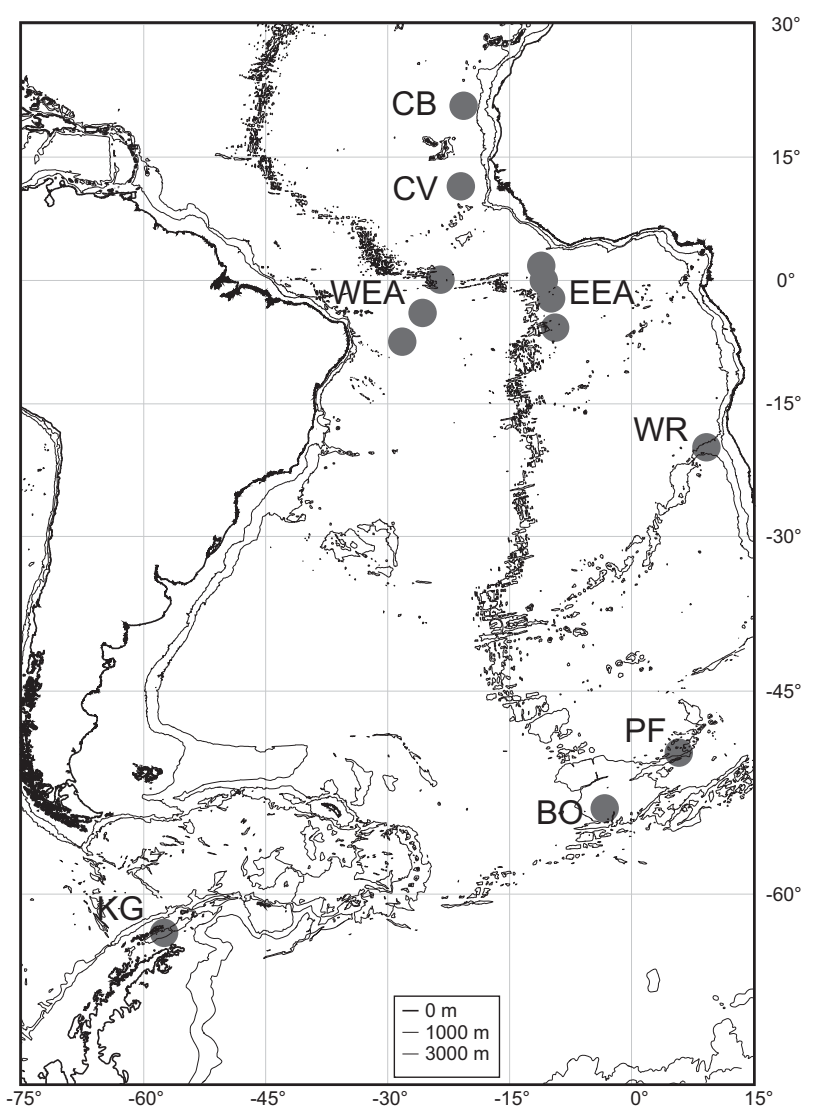

Fig. 1. Locations of the sediment trap mooring sites in the Atlantic Ocean (see Table 1). WEA = Western Equatorial Atlantic, EEA = Eastern Equatorial Atlantic. $\mathrm{CB}=\mathrm{Cape}$ Blanc, $\mathrm{CV}=$ Cape Verde Islands; $\mathrm{BO}=$ Bouvet Island; $\mathrm{WR}=$ Walvis Ridge $; \mathrm{PF}=$ Polar Front; $\mathrm{KG}=$ King George Basin.

flux magnitudes may be biased. Nevertheless, it is unlikely that sinking velocities are strongly affected. We intended to avoid depths where lateral input of material enhanced particle flux which was previously observed in the Canary Island region (e.g. Neuer et al., 1997, 2002). For a detailed description of currents velocities and directions and the discussion of trapping efficiencies see Fischer et al. (1996a, site CB) and Fischer et al. (2000, 2002, Atlantic and Southern Ocean).

\subsection{Estimation of particle sinking rates}

To calculate sinking rates we used sediment traps from two different water depths (about $1000 \mathrm{~m}$ water depth and some $500 \mathrm{~m}$ above the seafloor, Table 1). Two approaches were applied, both using seasonal flux data to capture potential seasonal changes in particle sinking rates. The first one compared the time shift of major flux peaks of total mass, divided by the distance between both traps by half the sampling interval (at a one-cup shift). The second approach followed the method of Berelson (2002) who attempted to find the best fit 


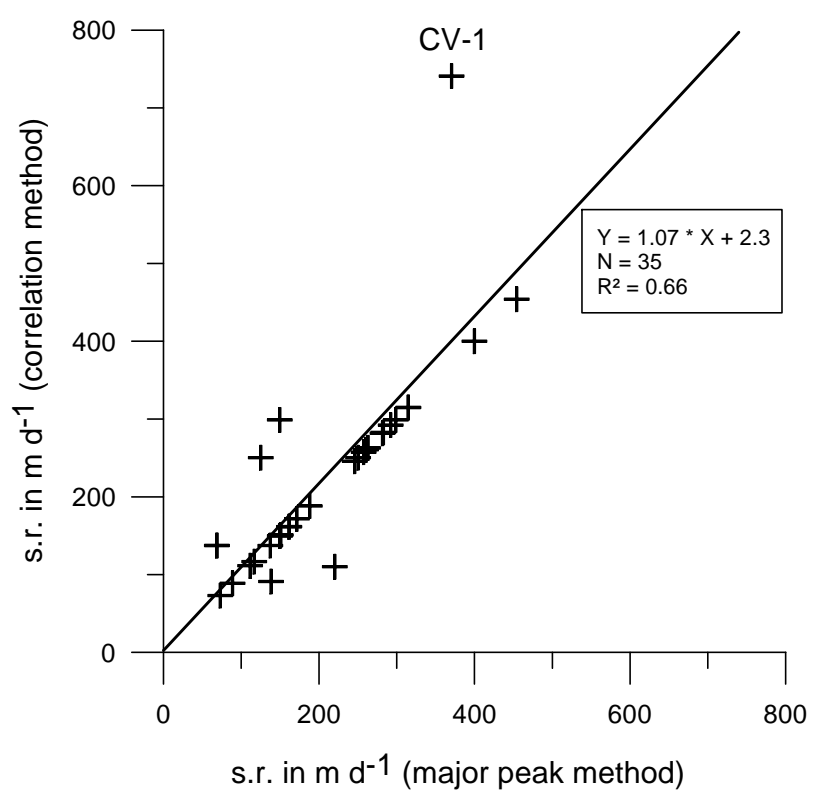

Fig. 2. Particle sinking rates determined by the major peak and the correlation method (Berelson, 2002). Note the significant correlation between both approaches $\left(R^{2}=0.66, N=35\right)$. When excluding the value of $\mathrm{CV}-1$, the correlation coefficient becomes even higher $\left(R^{2}=0.80, N=34\right)$.

between total flux at two water depths by shifting the complete time series by one or two sampling intervals. A comparison of both methods showed a close relationship with a correlation coefficient of $R^{2}=0.66(N=35$; Fig. 2) whereby the correlation method provides slightly higher sinking rates. When omitting the extreme sinking rate derived from one deployment at the Cape Verde site CV-1, the relationship between both methods was even better $\left(R^{2}=0.80, N=34\right)$. We applied the correlation method in our study as it is an established method (Berlson, 2002) and because it generally provided slightly higher sinking rates.

We further calculated sinking rates of alkenone-associated particles, mainly coccolithophorids, by determining the time shift between maxima/minima of measured SSTs (weekly, IGOSS; Reynolds and Smith, 1994; http://ingrid. ldgo.columbia.edu/SOURCES/.IGOSS/data_products.html) and alkenone-derived temperatures obtained from the trap samples (see Müller and Fischer, 2001, 2003) or by a comparison between alkenone-based temperatures from upper and lower trap levels. All estimated sinking rates must be regarded as the lowest estimates due to the relatively low time resolution for collection. The estimated sinking rates are dependent on the sampling intervals which range from 9.5 to 30 days (average 19.6 days, Table 1 ). To account for extreme differences in sampling intervals between the study sites, we could have normalized our sinking rates. However, only at a few locations, the sampling intervals strongly differed from the average of 19.6 days. This resulted in exceptionally high sinking rates only at site CV-1 (741 $\mathrm{m} \mathrm{d}^{-1}$; Table 1). Therefore, we did not normalize our values.

\subsection{Modeling particle fluxes}

A Regional Ocean Modelling System (ROMS) coupled to a seven-compartment biogeochemical model was applied to study deep water fluxes and their seasonal variation in the Cape Blanc region. ROMS is a well established terrainfollowing, hydrostatic, primitive equation ocean circulation model with orthogonal curvilinear horizontal coordinates. The numerical algorithms of the code are described in a series of papers by Shchepetkin and McWilliams (1998, 2003, 2005). The novelty in these algorithms is a split-explicit hydrodynamic kernel that treats baroclinic and barotrophic modes in such a way that ensures tracer conservation and prevents errors associated with unresolved barotrophic processes. Barotrophic fields are temporally averaged with a cosine-shape filter before replacing the values calculated with a longer baroclinic time step. By redefining barotrophic pressure-gradient terms according to the changes in local density fields, accuracy of the scheme is improved without compromising from computational efficiency.

The biogeochemical model was a classical, nitrogen based, NPZD-type, which was developed and defined in detail by Gruber et al. (2006). The model comprises seven compartments; nitrate, ammonium, phytoplankton, zooplankton, small and large detritus, and a dynamic phytoplankton chlorophyll to carbon ratio. Apart from zooplankton, all particulate compartments sink, which is modelled explicitly. Small particles are represented by a slow settling small detritus pool. Small detritus and phytoplankton coagulate to form large detritus, which sink faster. Coagulation is parameterised according to a particle density function based on the assumption that coagulation is proportional to particle concentration. Parameter values of the biogeochemical model are given in Gruber et al. (2006). These values remained unchanged in our configuration apart from the remineralisation rates of small and large detritus, specific coagulation rate between small detritus and phytoplankton, and large detritus sinking velocity.

Particles sink into the ocean's floor in a complex process with varying sinking velocities depending on their constituents, size, shape, porosity and way of formation (Kriest, 2002). A variety of sinking velocities have been observed at the Cape Blanc site (see Table 3). Because the small detritus pool represents particles with minimum diameter in the system, in our configuration the settling velocity of this class remained the same as in the original model $\left(1 \mathrm{~m} \mathrm{~d}^{-1}\right)$. With regard to the sinking of large detritus we used estimations of Helmke et al. (2005). By looking into the delay between chlorophyll maxima at the surface and the corresponding sedimentation peaks in the deep trap at $3580 \mathrm{~m}$, Helmke et 


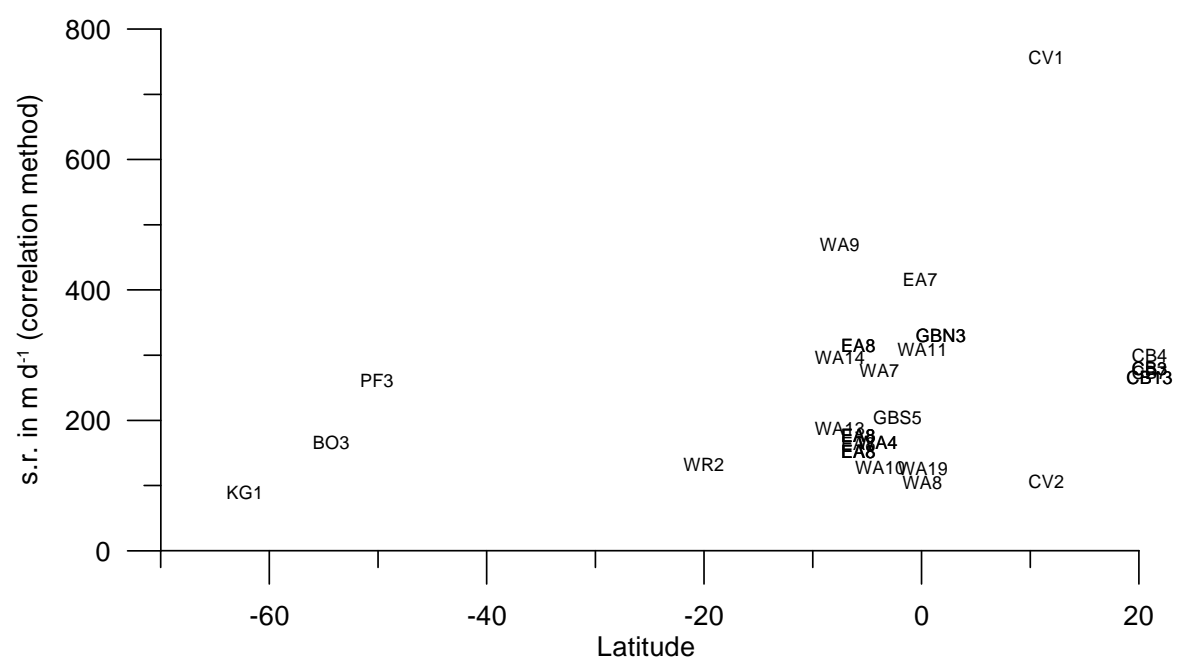

Fig. 3. Sinking rates of particles (applying the correlation method) collected during different seasons in the Atlantic Ocean (Table 1) and plotted versus latitude.

al. (2005) calculated a mean downward particle flux velocity for the entire water column of $75 \mathrm{~m} \mathrm{~d}^{-1}$ at this site. We therefore set the sinking velocity of large particles to $75 \mathrm{~m} \mathrm{~d}^{-1}$ in the model setup. Due to the seasonal variation (see Sect. 3.3) we increased sinking velocity by a factor of 2 below the euphotic layer in summer, which corresponds to trap samples \#3 through \#5.

In a parallel manner, particle remineralisation and specific coagulation rates are also increased in the present setup in order to maintain the export production rate of the original configuration. While remineralisation rates for small and large particles were set to $0.18 \mathrm{~d}^{-1}$ and $0.06 \mathrm{~d}^{-1}$, respectively, particle coagulation rate was specified as $0.07 \mathrm{~d}^{-1}$ $\left.(\mathrm{mmol} \mathrm{m})^{-3}\right)^{-1}$. The rate of increase in the remineralisation was similar to that of particle settling rate so that the remineralisation length scale can be preserved. Despite this increase, measurements of comparable remineralisation rates for marine snow were reported (Ploug and Grossart, 2000; Ploug et al., 2008a) and these values appear to be realistic. Small detritus remineralises three times faster than the large detritus in the original model (Gruber et al., 2006), which is left unchanged in this study as well. Moriceau et al. (2007) points to a similar ratio of silica dissolution rates between aggregated and freely suspended diatoms.

Our model domain covers the region between $5^{\circ}$ to $41^{\circ} \mathrm{N}$ and $30^{\circ}$ to $5.5^{\circ} \mathrm{W}$, and has a resolution of $12 \mathrm{~km}$. GEBCO data (IOC, IHO and BODC, 2003) was used to produce model bathymetry. In the vertical $32 \mathrm{~s}$-coordinate levels are set with increasing resolution towards the surface. World Ocean Atlas 2001 (WOA2001) (Stephens et al., 2002; Boyer et al., 2002) climatology is used for the initialisation of the model from a state of rest in January. Monthly means of this climatology is employed along the lateral boundaries to prescribe temperature, salinity, nutrient and momentum fluxes. The model is forced with monthly averaged COADS (Comprehensive Ocean-Atmosphere Data Set) for the heat, fresh water and momentum fluxes (da Silva et al., 1994) during spin-up. After 3 years of spin-up the model was forced by 6-hourly NCEP reanalysis-2 data (Kanamitsu et al., 2002) for the years 2002 and 2003, i.e. during the time sediment trap data were collected at the mesotrophic CB-13 deployment site off Cape Blanc.

\section{Results and discussion}

\subsection{Regional variability of particle sinking rates}

Sinking rates of particles determined from sediment trap samples range from 73 to $741 \mathrm{~m} \mathrm{~d}^{-1}$ applying the correlation method (Table 1). At site CV (Cape Verde Islands, Fig. 1), we obtained a large interannual variability of sinking rates which may at least be partly due to exceptionally different sampling intervals of 9.5 and 25 days (Table 1). Although the high value derived from deployment CV-1 must be regarded with caution, the total range of sinking rates could be reasonable, thus pointing towards a high interannual variability of sinking rates at his site. The regional, seasonal and interannual variability of particle sinking rates versus latitude is shown in Fig. 3. Relatively low sinking rates were obtained in the Southern Ocean, at the Walvis Ridge and in the western Equatorial Atlantic, highest values were found in the eastern Equatorial Atlantic and off NW Africa. Mean sinking rates and their standard deviations are given in Fig. 4e together with the composition of sinking particles (\% of total annual mass) from the upper trap collections (Table 1), including mean sinking rates for the silicate-rich Equatorial Pacific $\left(158 \mathrm{~m} \mathrm{~d}^{-1}\right)$ and the Arabian Sea $\left(230 \mathrm{~m} \mathrm{~d}^{-1}\right)$ (Berelson, 2002). 


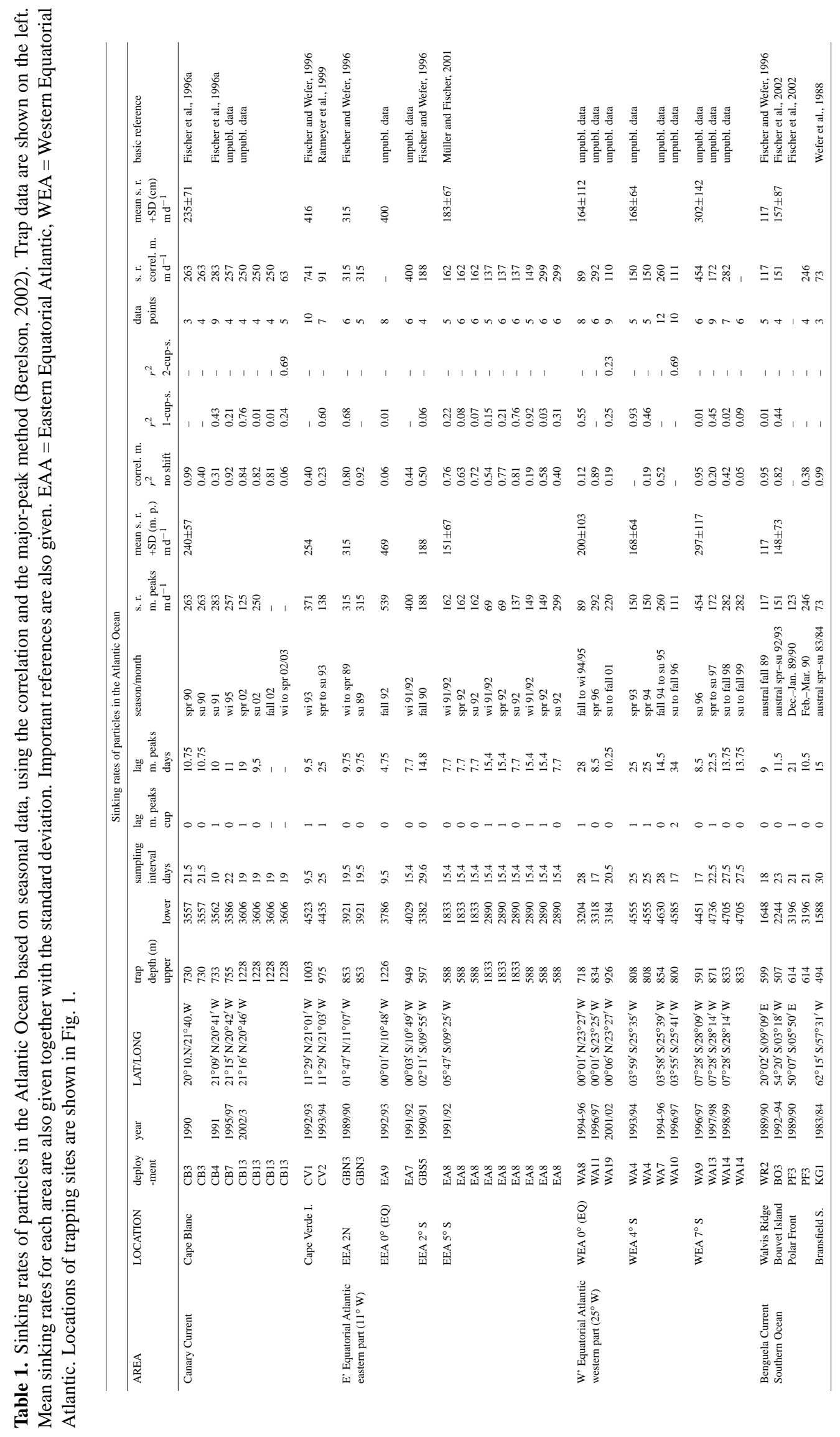


Although the seasonal and interannual variability is significant, we observe highest mean sinking rates close to the equator in the Eastern Atlantic and off NW Africa, which corresponds roughly to highest organic carbon and carbonate contents (Fig. 4). Consequently, biogenic opal contents remain low there. Mean sinking rates from the Arabian Sea, a production system with high carbonate and low biogenic opal (De La Rocha and Passow, 2007), are also relatively high. The Equatorial Pacific, however, a production system characterized by biogenic opal sedimentation (Ragueneau et al., 2000) provided lower sinking rates. Highest particle sinking rates in carbonate-dominated production systems correspond at first sight to the global distribution of organic carbon transfer efficiency which is higher in carbonate (equatorial regions) compared to biogenic opal production systems (polar or subpolar regions). Francois et al. (2002) speculated that this might reflect a fundamental difference in the type of particle transport, i.e. fast sinking fecal pellets in carbonate - versus slowly sinking diatom aggregates in opal production systems. However, a statistically valid relationship between particle sinking rates and carbonate content was not found using the regional data shown in Fig. 4. This may be explained by a variable and largely unknown composition of total carbonate in the modern ocean, i.e. mainly coccolithophorids versus planktonic foraminifera. Total carbonate appears to be mostly composed of coccolithophorids, but foraminifera may contribute up to $50-70 \%$ of the total carbonate flux (Berner and Honjo, 1981; Schiebel, 2002). In contrast to small coccoliths, foraminifera appear to sink mainly individually, not within larger composite particles and should not be included in the carbonate flux when discussing carbonate ballasting effects for the sedimentation of aggregated organic carbon-rich particles. De La Rocha and Passow (2007) showed that sedimentation of foramineral calcite does not appear to be as tightly linked to POC flux as coccolith sedimentation.

Coccoliths are thought to be transported mainly within dense and fast sinking pellets (Honjo, 1976; Knappertsbusch and Brummer, 1995), thus transporting organic carbon and other organic components (e.g. chlorophyll derivates) very efficiently to greater depth (Fischer et al., 1996b). Fecal pellets generally have higher sinking rates $\left(10-2700 \mathrm{~m} \mathrm{~d}^{-1}\right.$, Angel, 1984, 1989; Fowler and Knauer, 1986; Cadée et al., 1992; Bruland and Silver, 1981; Turner, 2002) than the less denser and TEP-rich marine snow aggregates (16-26 $\mathrm{m} \mathrm{d}^{-1}$ from Pilskaln et al., 1998; $10 \mathrm{~m} \mathrm{~d}^{-1}$ (mean); from Dierks and Asper, 1997; 1-36 $\mathrm{m} \mathrm{d}^{-1}$ from Asper, 1987; 100-150 $\mathrm{m} \mathrm{d}^{-1}$ from Smetacek, 1985; Billet et al., 1983; Alldredge and Gotschalk, 1989; 1-368 $\mathrm{m} \mathrm{d}^{-1}$ from Alldredge and Silver, 1988), although the range of sinking rates for both type of larger particles overlap. In coastal settings of the Ross Sea, diatom aggregates may have sinking rates higher than $288 \mathrm{~m} \mathrm{~d}^{-1}$ (Asper and Smith, 2003). At the Antarctic Polar Front, diatoms may be rapidly transferred downwards to the sediment via large chains of larger cells (Dubischar
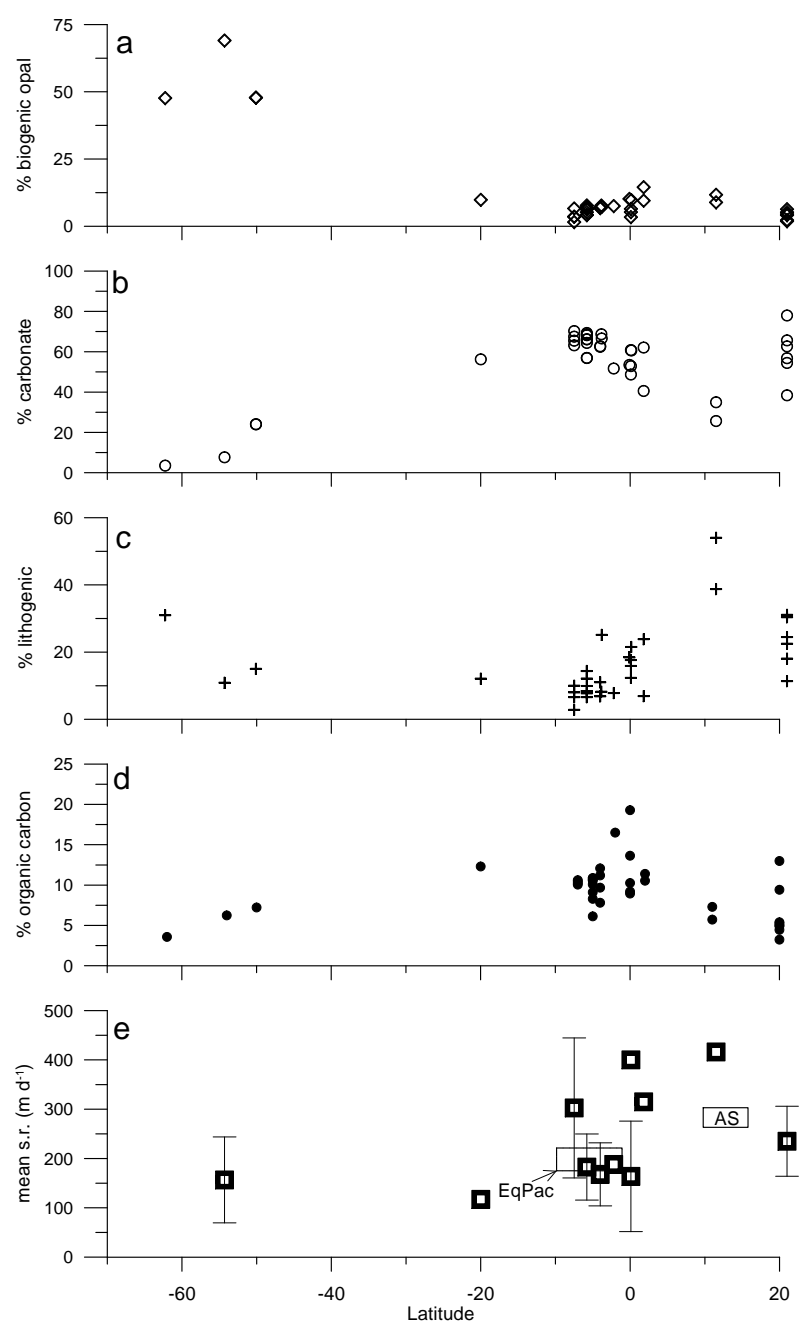

Fig. 4. Mean sinking rates of particles (e, with standard deviation) and particle compositions of the upper traps (a-d, \% of total annual mass) in the Atlantic Ocean based on seasonal time resolution (Table 1). In (e), average sinking rates determined for the Equatorial Pacific (EqPac) and the Arabian Sea (AS) are also given (Berelson, 2002). Note the highest mean sinking rates at the Equator and off NW Africa.

and Bathmann, 2002). We also obtained an overlap of the sinking rates between the two different production systems (Fig. 4e), but the highest rates occurred in carbonate and dust-dominated areas at the eastern equator and off $\mathrm{NW}$ Africa.

Although the lithogenic content of particle flux from the entire Atlantic does not show an overall significant relationship to particle sinking rates, the distribution pattern shown in Fig. 4 suggests some effect of dust minerals. For example, mean particle sinking rates decrease from about 315 to $183 \mathrm{~m} \mathrm{~d}^{-1}$ in the eastern Atlantic in a southward direction (Table 1), concomitant with a decrease in the flux of lithogenic materials (Fischer and Wefer, 1996). The northern 
Table 2. Sinking rates of particles calculated from alkenone measurements from the Cape Blanc deployments (at site CB; Müller and Fischer, 2001 and unpubl. data). Note the increase of mean sinking rates with depth (from 51 to 108 to $318 \mathrm{~m} \mathrm{~d}^{-1}$ ) and the extraordinary high rates of $566 \mathrm{~m} \mathrm{~d}^{-1}$ in 1991 (CB-4) during the sedimentation of a summer coccolithophorid bloom.

\begin{tabular}{|c|c|c|c|c|c|c|c|c|c|c|c|}
\hline \multicolumn{12}{|c|}{ Sinking rates from alkenone measurements of the Cape Blanc deployments } \\
\hline Trap deployment & CB1 & CB2 & CB3 & CB3 & CB3 & CB4 & CB4 & CB4 & CB13 & CB13 & CB13 \\
\hline year & 1988 & 1989 & 1990/91 & 1990/91 & 1990/91 & 1991 & 1991 & 1991 & $2002 / 03$ & $2002 / 03$ & $2002 / 03$ \\
\hline lag of peaks (cup) & - & - & - & - & 0 & - & - & 0 & - & - & 1 \\
\hline lag of peaks (days) & 25 & 45 & 48 & 48 & 10.75 & 10 & 10 & 5 & 19 & 36 & 19 \\
\hline season & summer & summer & summer & summer & summer & summer & summer & summer & late summer & late w./late su. & late w./late su. \\
\hline depths (m) & 0 & 0 & 0 & 0 & 730 & 0 & 0 & 733 & 0 & 0 & 1228 \\
\hline & 2195 & 3502 & 730 & 3557 & 3557 & 733 & 3562 & 3562 & 1228 & 3606 & 3606 \\
\hline $\begin{array}{l}\text { sinking rates } \\
\left(\mathrm{m} \mathrm{day}^{-1}\right)\end{array}$ & 88 & 78 & 15 & 74 & 263 & 73 & 356 & 566 & 65 & 100 & 125 \\
\hline $\begin{array}{l}\text { sampling intervals } \\
\text { (days) }\end{array}$ & 27 & 17 & 21.5 & 21.5 & 21.5 & 10 & 10 & 10 & 19 & 19 & 19 \\
\hline reference & $\begin{array}{l}\text { M. and F., } \\
2001\end{array}$ & $\begin{array}{l}\text { M. and F., } \\
2001\end{array}$ & $\begin{array}{l}\text { M. and F., } \\
2001\end{array}$ & $\begin{array}{l}\text { M. and F., } \\
2001\end{array}$ & $\begin{array}{l}\text { M. and F., } \\
2001\end{array}$ & $\begin{array}{l}\text { M. and F., } \\
2001\end{array}$ & $\begin{array}{l}\text { M. and F., } \\
2001\end{array}$ & $\begin{array}{l}\text { M. and F., } \\
2001\end{array}$ & $\begin{array}{l}\text { unpubl. } \\
\text { data }\end{array}$ & $\begin{array}{l}\text { unpubl. } \\
\text { data }\end{array}$ & $\begin{array}{l}\text { unpubl. } \\
\text { data }\end{array}$ \\
\hline
\end{tabular}

sites (EEA $2^{\circ} \mathrm{N}$, EEA $0^{\circ}$ ) having relatively high mean sinking rates $\left(315-400 \mathrm{~m} \mathrm{~d}^{-1}\right)$ are strongly influenced by the migration of the ITCZ bringing fine-grained lithogenic components (dust) into the oceanic environment. As sinking rates are to a large part derived from winter and spring sedimentation, the time of the southernmost extension of the ITCZ, an impact of dust is plausible. To clarify the potential role of mineral dust vs. coccolith-carbonate for ballasting off NW Africa is another issue and requires further detailed studies in the field and laboratory. Different ballast minerals from dust such as kaolinite, smectite or quartz may have different effects on sinking rates of aggregates as shown in laboratory studies (Hamm, 2002). When discussing particle sinking rates, not only mass properties of larger particles (e.g. composition, density) have to be considered as in this study, but also the size and shape of aggregates (De La Rocha and Passow, 2007). However, the latter issue requires other, nondestructive methods such as in situ optical techniques.

\subsection{Coccolithophorid-associated particle sinking rates}

Here we use alkenones which are thought to be produced mainly by coccolithophorids and we calculated sinking rates associated primarily with these organisms (Müller and Fischer, 2001, 2003). This approach not only allows the estimation of particle sinking rates in the bathypelagic by comparing trap results from the upper and lower traps but also the assessment of average sinking rates in the mesopelagic zone by comparing measured SST with the reconstructed temperatures of the upper trap samples derived from alkenone measurements (Müller and Fischer, 2001, 2003). Sinking rates from the mesopelagic are an interesting issue as they document the sum of aggregation-disaggregation processes and the complexity of the food web structure occurring in this zone of high organic carbon remineralization. We obtained unusually low sinking rates of $9 \mathrm{~m} \mathrm{~d}^{-1}$ in the Southern Ocean (site PF-3, 0-613 m water depth), probably due to a long range lateral displacement of particles within the deep-reaching, constantly eastward flowing Antarctic Circumpolar Current (ACC) with relatively high current velocities (Müller and Fischer, 2003). Advection of water masses and transport of larger particles over laterally significant distances from their point of origin is also described by Gorsky et al. (2003). This shows that coccoliths are not transported rapidly downwards via fast sinking fecal pellets everywhere. A long-range transport is also proposed from the sinking rates of coccolith-associated particles in the eastern equatorial Atlantic (site EA-8, Table 1; Müller and Fischer, 2003), with mean sinking rates in the order of $13 \mathrm{~m} \mathrm{~d}^{-1}$ for the water column between the surface and $598 \mathrm{~m}$. Higher values of $48 \mathrm{~m} \mathrm{~d}^{-1}$ were recorded for the Benguela System (trap WR-2-4), however, between the surface and $1648 / 1717 \mathrm{~m}$. At site NU-2 off Namibia, $45 \mathrm{~m} \mathrm{~d}^{-1}$ was estimated between the surface and $2516 \mathrm{~m}$. These observations point to increasing sinking rates with depth for alkenone-containing particles. Sinking of coccolithophorid mats containing mucus in the Panama Basis was in the order of $65 \mathrm{~m} \mathrm{~d}^{-1}$ (Honjo, 1982), thus being well within our range of values. Sawada et al. (1998) found sinking rates of alkenone-associated particles in the western Pacific off Japan of $145-290 \mathrm{~m} \mathrm{~d}^{-1}$, but for the entire water column of $8000 \mathrm{~m}$. Marine snow aggregates formed by coccolithophorids, the major primary producers of carbonate in the ocean (Berner and Honjo, 1981; Schiebel, 2002) have not yet been observed (de la Rocha and Passow, 2007). The upwelling filament off Cape Blanc was studied in more detail (Müller and Fischer, 2001 and unpubl. data), indicating high interannual variability of sinking rates and associated transport processes. We obtained sinking rates for the mesopelagic between 15 and $73 \mathrm{~m} \mathrm{~d}^{-1}$ (Table 2), being within the range of values from the Atlantic Ocean described above. These relatively low rates might indicate a significant lateral displacement of larger particles from their point of origin, most probably from the coast (e.g. Karakaş et al., 2006). Values between the surface and the deep traps were between 73 and $100 \mathrm{~m} \mathrm{~d}^{-1}$ for the 
Table 3.Summary of sinking rates derived from this study (Tables 1,2) in comparison to literature values for fecal pellets and marine snow aggregates.

\begin{tabular}{|c|c|c|c|c|c|c|}
\hline \multicolumn{7}{|c|}{ Summary of sinking rates } \\
\hline method & region & study sites & $\begin{array}{l}\text { sinking rate } \\
\mathrm{m} \mathrm{d}^{-1} \\
\text { (corr. method) }\end{array}$ & $\begin{array}{c}\text { depth range } \\
\mathrm{m}\end{array}$ & remark & reference \\
\hline \multirow[t]{8}{*}{ flux patterns } & Northeast Atlantic & see Table 1 & 326 & $730-4523 \mathrm{~m}$ & mean & this study \\
\hline & Eastern Eq. Atlantik & see Table 1 & 299 & $597-4029 \mathrm{~m}$ & mean & this study \\
\hline & Western Eq. Atlantik & see Table 1 & 211 & $718-4736 \mathrm{~m}$ & mean & this study \\
\hline & Southeast Atlantic & WR, see Table 1 & 117 & $599-1648 \mathrm{~m}$ & & this study \\
\hline & Southern Ocean & see Table 1 & 157 & $494-3196 \mathrm{~m}$ & mean & this study \\
\hline & Cape Blanc & $\mathrm{CB}$ & 235 & $730-3606 \mathrm{~m}$ & mean & this study \\
\hline & Cape Blanc & CB13 & 63 & $1228-3606 \mathrm{~m}$ & winter-spring bloom & this study \\
\hline & Cape Blanc & CB13 & 250 & $1228-3606 \mathrm{~m}$ & summer & this study \\
\hline flux patterns/ & Cape Blanc & CB9 & 90 & surface to $3600 \mathrm{~m}$ & winter-spring bloom & from Helmke et al., 2005 \\
\hline chlorophyll & Cape Blanc & CB9 & 120 & surface to $3600 \mathrm{~m}$ & summer & from Helmke et al., 2005 \\
\hline \multirow[t]{7}{*}{ alkenones } & Cape Blanc & $\mathrm{CB} 1,2,3,4,13$ & 51 & surface - upper traps & Table 2, mean & this study \\
\hline & & $\mathrm{CB} 1,2,3,4,13$ & 108 & surface - deep traps & Table 2, mean & \\
\hline & & $\mathrm{CB} 1,2,3,4,13$ & 318 & upper - deep traps & Table 2, mean & \\
\hline & Polar Front & PF3 & 9 & surface to $613 \mathrm{~m}$ & & Müller and Fischer, 2003 \\
\hline & Eastern Equatorial Atlantic & EA8 & 13 & Surface to $598 \mathrm{~m}$ & & Müller and Fischer, 2003 \\
\hline & Namibia upwelling & NU1 & 45 & Surface to $2516 \mathrm{~m}$ & & Müller and Fischer, 2003 \\
\hline & Walvis Ridge & WR2-4 & 48 & Surface to $1648 / 1717 \mathrm{~m}$ & & Müller and Fischer, 2003 \\
\hline alkenones & Western Pacific off Japan & - & $145-290$ & surface to $8688 \mathrm{~m}$ & - & Sawada et al., 1998 \\
\hline sediment trap fluxes & Eastern Equatorial Pacific & - & 150 & surface to $5000 \mathrm{~m}$ & coccol. fecal pellets & Honjo, 1976 \\
\hline sediment trap fluxes & Panama Basin & - & 65 & surface to $3860 \mathrm{~m}$ & mucus coccol. mats & Honjo, 1982 \\
\hline- & - & - & 100 & - & diatom flocs & Smetacek, 1985 \\
\hline settling chambers & Monterey Bay, Calif. & - & $43-95$ & surface ocean & marine snow & Shanks and Trent, 1980 \\
\hline photography & Northeast Atlantic & - & $100-150$ & surface to seafloor & diatom aggregates & Billet et al., 1983 \\
\hline in situ observations & Santa, B. channel, Calif. & - & $117 \pm 56$ & surface & diatom flocs & Alldredge and Gotschalk, 1989 \\
\hline photography & coastal Ross Sea & - & $>288$ & shelf waters & diatom aggregates & Asper and Smith, 2003 \\
\hline
\end{tabular}

deployments CB-1-3 and CB-13, respectively, again pointing to increasing sinking rates with depth. During deployment CB-4 in summer 1991, sinking rates were $356 \mathrm{~m} \mathrm{~d}^{-1}$ between the surface and $3562 \mathrm{~m}$ (Table 2). Between the upper trap and the lower trap, sinking rates were even as high as $566 \mathrm{~m} \mathrm{~d}^{-1}$. During this year organic carbon transfer and the alkenone flux to depth were extraordinary high, even though production at the surface was assumed to be even decreasing (Müller and Fischer, 2001; Fischer et al., 2009). When calculating the coccolith flux from total carbonate flux (by counting and weighing planktic foraminifera and pteropods), we found that almost all carbonate $(95 \%)$ was supplied by coccoliths in 1991. In contrast, during deployment CB3 (1989), we obtained a contribution of coccolith-carbonate in the order of only $65 \%$. We assume that an episodic pulse of a coccolithophorid bloom in 1991 (CB-4) was exported rapidly in a vertical direction leading to an effective transfer of carbon through rapidly sinking fecal pellets. Coccoliths being densely packed within fast sinking fecal pellets (around $150 \mathrm{~m} \mathrm{~d}^{-1}$ ) were described by Knappertsbusch and Brummer (1995) from the North Atlantic near NABE $48^{\circ} \mathrm{N}$. Zooplankton fecal pellets with coccoliths were also described from the Equatorial Pacific and had sinking rates of $150 \mathrm{~m} \mathrm{~d}^{-1}$ (Honjo, 1976). These values are close to our average coccolith-associated sinking rates for the entire water column off Cape Blanc which were around $160 \mathrm{md}^{-1}$
(Table 3). But our peak value of $566 \mathrm{~m} \mathrm{~d}^{-1}$ appears to be also reasonable when considering sinking rates given by Cherry et al. $\left(1978,50-950 \mathrm{~m} \mathrm{~d}^{-1}\right)$, Fowler and Small $(1972,126-$ $\left.862 \mathrm{~m} \mathrm{~d}^{-1}\right)$ or Cadée et al. $\left(1992,50-800 \mathrm{~m} \mathrm{~d}^{-1}\right)$.

We collected mesozooplankton fecal pellets made up to a large part of densely packed coccoliths at the ESTOC site in the Canary Current in 1992. They transported rather fresh organic detritus to greater depth providing a perfect correspondence between seasonal organic carbon and carbonate flux (Fischer et al., 1996b). In addition, we found $1000 \mu \mathrm{m}$ long and very densely packed appendicularian pellets in the sediment trap collections at the coastal eutrophic site off Cape Blanc ( $\mathrm{CB}_{\text {coastal }}-2$ : $1296 \mathrm{~m}$ trap depth, unpubl. data) which contain large amounts of coccoliths and which sink with rates of about $732 \pm 153 \mathrm{~m} \mathrm{~d}^{-1}$ as determined by a flow velocimeter (Ploug et al., 2008b). Experimental studies support our field observations; M. Iversen and H. Ploug from the MPI in Bremen (unpubl. data) obtained significantly higher particle sinking rates in artificial aggregates containing coccoliths compared to those with diatoms. De La Rocha and Passow (2007) obtained more compact, less porous aggregates when adding fine-grained carbonate which resulted in increased particle sinking velocities. 


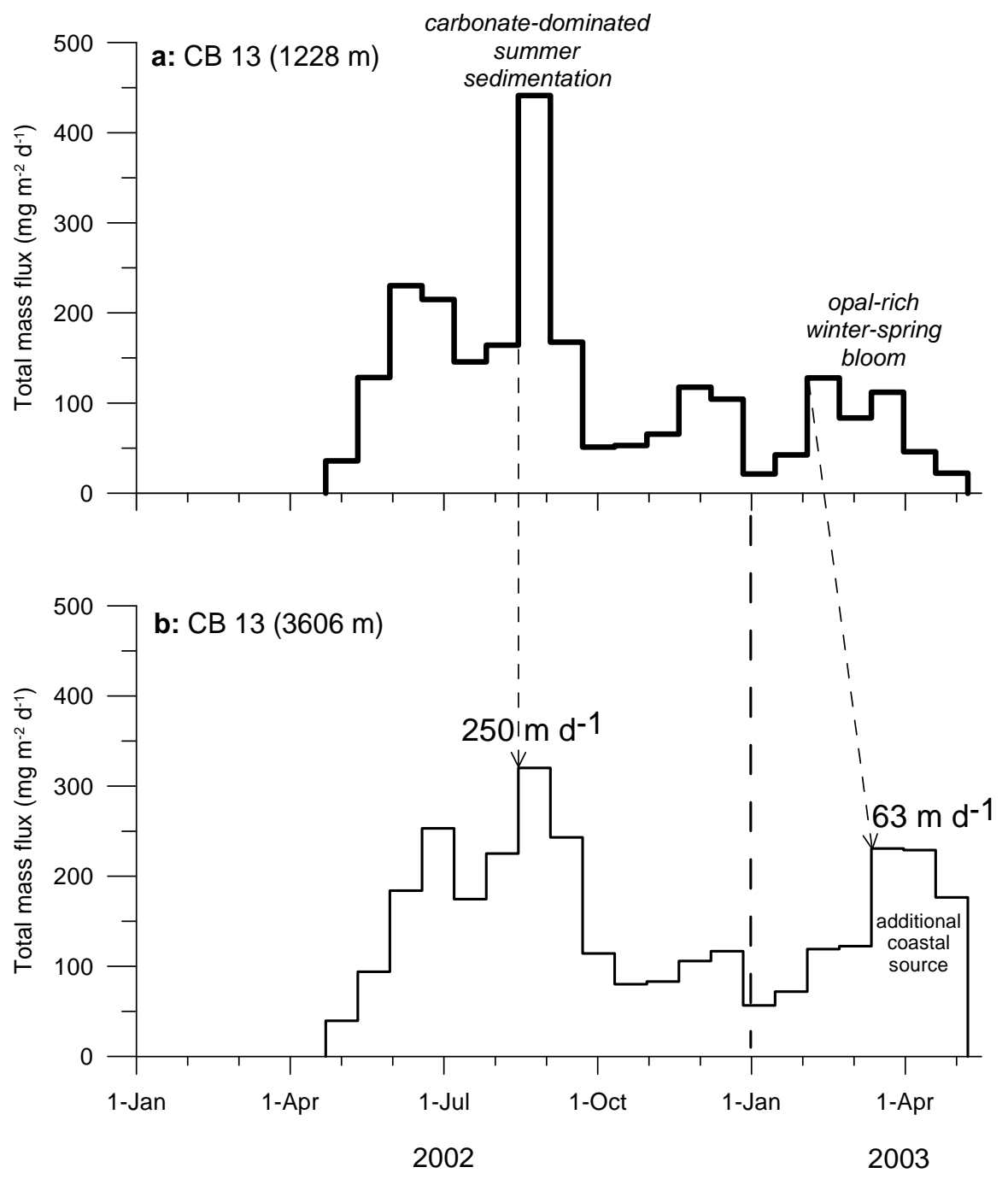

Fig. 5. Typical total mass flux patterns of upper (a) and lower traps (b) at the mesotrophic Cape Blanc site CB (deployment 13: spring 2002 to spring 2003) (Table 1). Note the time shift in winter-spring peak combined with an increase in fluxes with depth, which points to an additional particle source at the coast (Karakaş et al., 2006). A similar flux pattern between the upper and lower trap without any delay in major peaks was observed for the late spring and summer season. Accordingly, sinking rates change from $63 \mathrm{~m} \mathrm{~d}^{-1}$ in spring to $250 \mathrm{~m} \mathrm{~d}^{-1}$ in summer between 1228 and $3606 \mathrm{~m}$ water depth.

\subsection{Seasonal variability of particle sinking rates}

In the coastal upwelling setting off Cape Blanc, an E-W transect of surface chlorophyll from SeaWiFs and sediment trap data from deployment CB-9 were used to track the seasonal chlorophyll signals, to determine the source region of particles settling through the water column and to study the relationship between chlorophyll and deep ocean organic carbon fluxes (Helmke et al., 2005). We applied these data to calculate seasonal sinking rates of particles between the surface and $3600 \mathrm{~m}$ water depths (CB-9 deployment). We obtained higher sinking rates of about $120 \mathrm{~m} \mathrm{~d}^{-1}$ during the late summer/early fall season when coccolithophorid production was enhanced. During the winter-spring bloom with enhanced biogenic opal sedimentation, sinking rates were only around $90 \mathrm{~m} \mathrm{~d}^{-1}$. A similar pattern is found for the CB13 deployment (Fig. 5) when applying total flux data from the upper $(1228 \mathrm{~m})$ and the lower trap $(3606 \mathrm{~m})$. The winterspring peak measured with the upper trap appeared two cups later in the deep trap where the particle flux is almost twice as high, pointing to an additional particle source, most probably at the coast (Karakaş et al., 2006). This delay translates into a sinking rate of $63 \mathrm{~m} \mathrm{~d}^{-1}$ during the winter-spring bloom. The carbonate-dominated summer sedimentation in the mesopelagic zone is almost perfectly reflected in the deep trap with some reduction in magnitude, as expected, but without any time shift, suggesting particle sinking rates of $250 \mathrm{~m} \mathrm{~d}^{-1}$. 


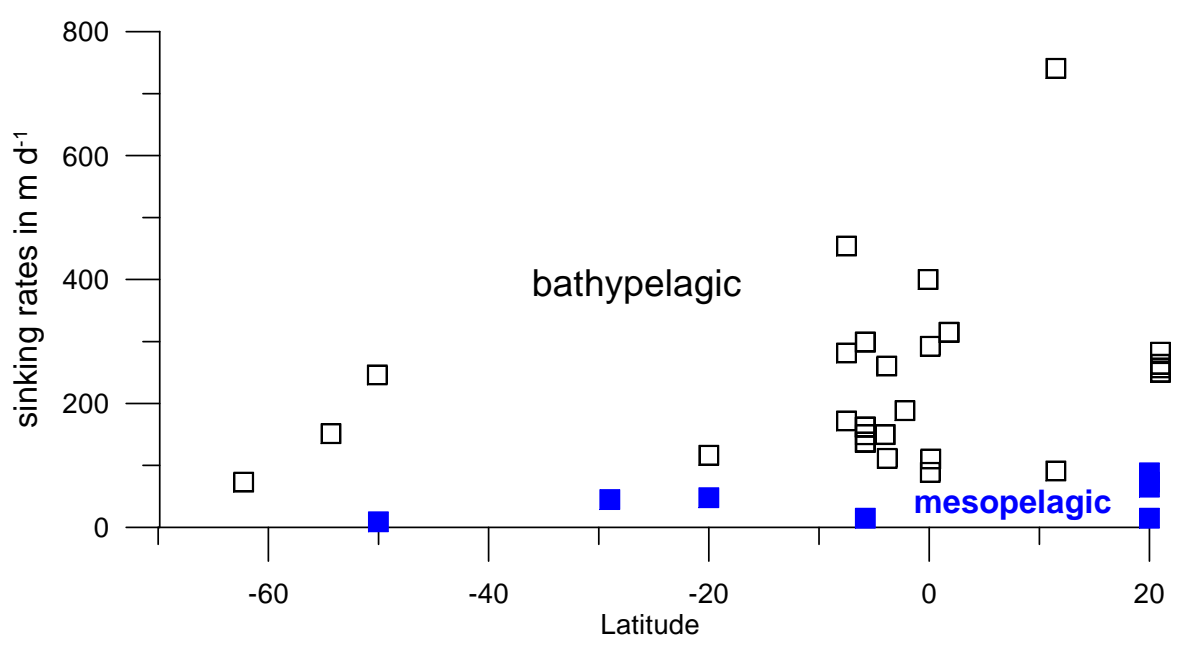

Fig. 6. Sinking rates of particles estimated for the mesopelagic zone (filled squares, from alkenone analysis, Müller and Fischer, 2001, 2003) compared to sinking rates (correlation method, Table 1) determined from flux patterns of upper and lower traps (bathypelagic zone; open squares). Note that all sinking rates from the bathypelagic zone exceed those estimated for the upper water column, suggesting increasing sinking rates with depth.

\subsection{Variability of particle sinking rates with depth}

Sinking rates derived from alkenone analysis and SST measurements suggest an increase with water depth, e.g. from 15 to $263 \mathrm{~m} \mathrm{~d}^{-1}$ at site CB-3, 73 to $566 \mathrm{~m} \mathrm{~d}^{-1}$ at site CB-4 and 65 to $125 \mathrm{~m} \mathrm{~d}^{-1}$ at site CB-13 (Table 2). All these values from the deeper water column fall within the range of sinking rates derived from the flux patterns, pointing to almost similar values for total material and coccolith-associated carbon and carbonate. In Fig. 6, we plotted the latitudinal distribution of sinking rates from shallower depths (derived from alkenones, Table 2) and those from the deeper water column taken from flux comparisons (Table 1). All values from the deeper water column exceed the sinking rates from shallower waters.

Increasing sinking rates of particles have important implications for the degradation of organic carbon and particle remineralisation rates in general. Studies modelling particle transport paths currently operate with fixed sinking rates for the entire water column (e.g. Karakaş et al., 2006; Gruber et al., 2006). Lower sinking rates in the mesopelagic zone (e.g. around $50 \mathrm{~m} \mathrm{~d}^{-1}$ off Cape Blanc, Table 2) may be explained by rather fresh material containing high amounts of organic material combined with relatively low contents of ballast minerals. In the mesopelagic, material may be processed through complex food webs (Legendre and Rivkin, 2002), thus increasing the residence time of materials in this part of the water column. Higher sinking rates in the bathypelagic may be caused by a loss of light organic materials (Berelson, 2002) and therefore a relative increase in ballast minerals. It is known from studies from the deeper water column that the amount of suspended material, e.g. fine-grained lithogenic components or tiny coccoliths (de La Rocha and
Passow, 2007) resuspended from the seafloor but also from the shelf (e.g. Karakaş et al., 2006) are enhanced and might be incorporated into larger particles (Nowald et al., 2006), thus increasing particle sinking rates.

\subsection{Simulated chlorophyll distribution and deep water fluxes}

The model produced physical and biogeochemical characteristics of the upwelling system reasonably well. The simulated hydrodynamic fields are presented by Karakaş et al. (2006) and Marchesiello and Estrada (2007). Herein, we explicitly focus on biogeochemical properties. Figure 7 shows annual surface chlorophyll fields for the year 2002 inferred from SeaWiFS and that of our simulation. Despite its relatively coarse resolution, the surface chlorophyll distribution was reproduced to a great extent. The model shows a slightly exaggerated offshore chlorophyll concentration to the North of Cape Juby, in the North and off Cape Verde in the South. In these locations, the $0.4 \mathrm{mg} \mathrm{m}^{-3}$ contour line in the model is around $100-150 \mathrm{~km}$ farther offshore than the one in the SeaWiFS data. Off Cape Blanc, on the other hand, which is the region of our interest, the spatial distribution is very similar. The study site $\mathrm{CB}$ for instance, where sediment data are recorded, lies under $0.4 \mathrm{mg} \mathrm{m}^{-3}$ contour line both in satellite data and modelled fields. Simulated near-shore values on the other hand appear to be weaker than remotely recorded data. While relatively coarse grid resolution could be one reason for this anomaly, the quality of remote sensing data in coastal regions could be another, which has been questioned in a number of studies (e.g. Gohin et al., 2002; Lavender et al., 2004; Harding et al., 2005). 

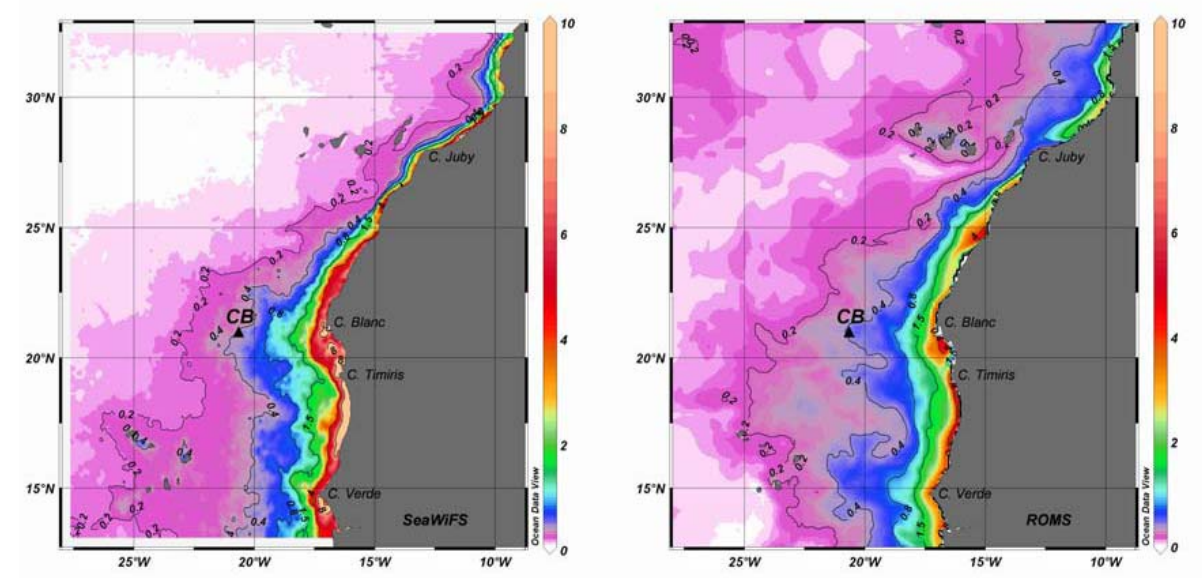

Fig. 7. Annual surface chlorophyll distribution $\left(\mathrm{mg} \mathrm{m}^{-3}\right)$ as observed by SeaWiFS (left) and modelled by ROMS (right) for the year 2002.
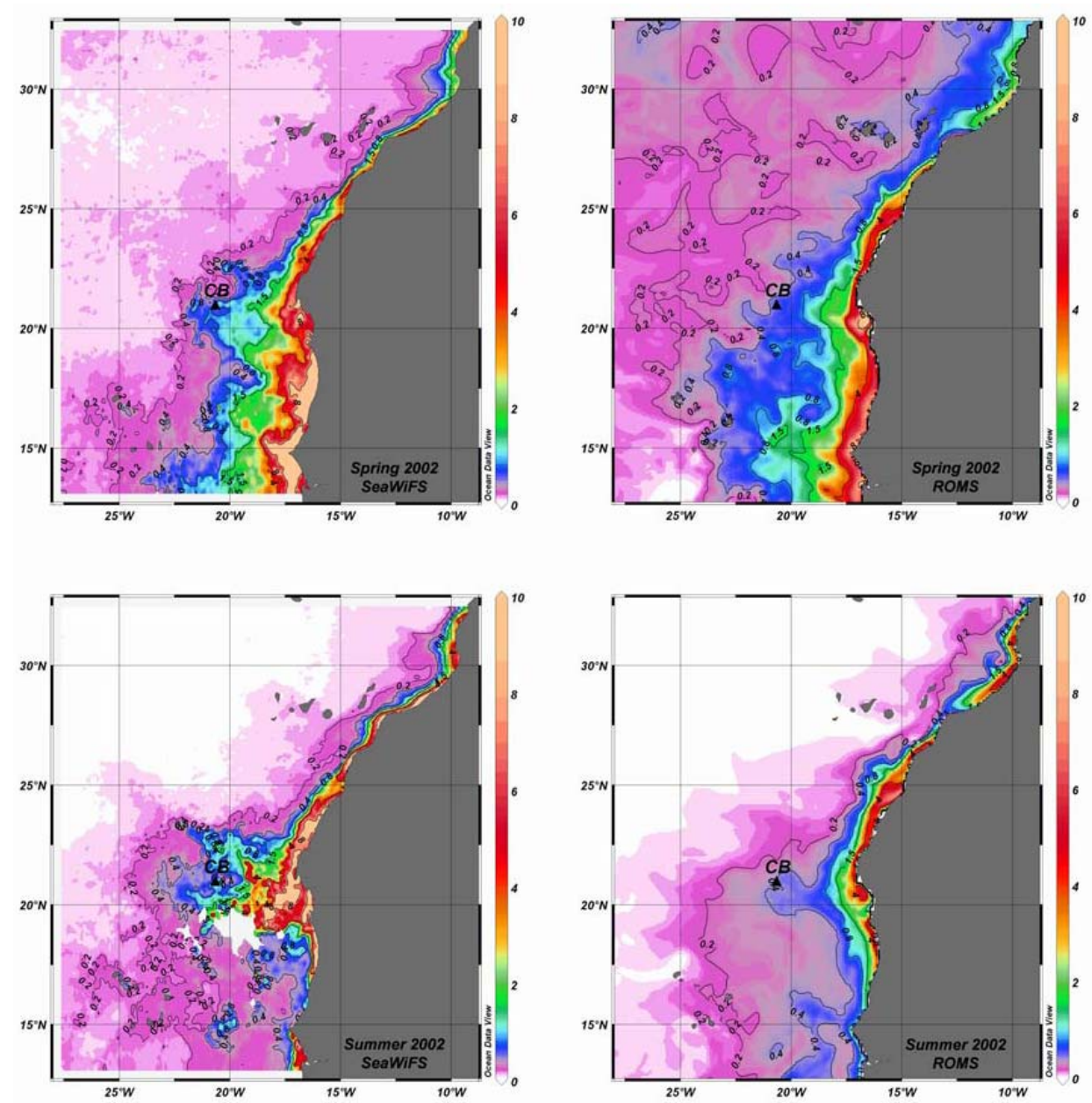

Fig. 8a. (a) Seasonal surface chlorophyll distribution $\left(\mathrm{mg} \mathrm{m}^{-3}\right)$ in spring (mid-March to mid-June) and summer (mid-June to midSeptember) 2002 as inferred by SeaWiFS and simulated by the model. 

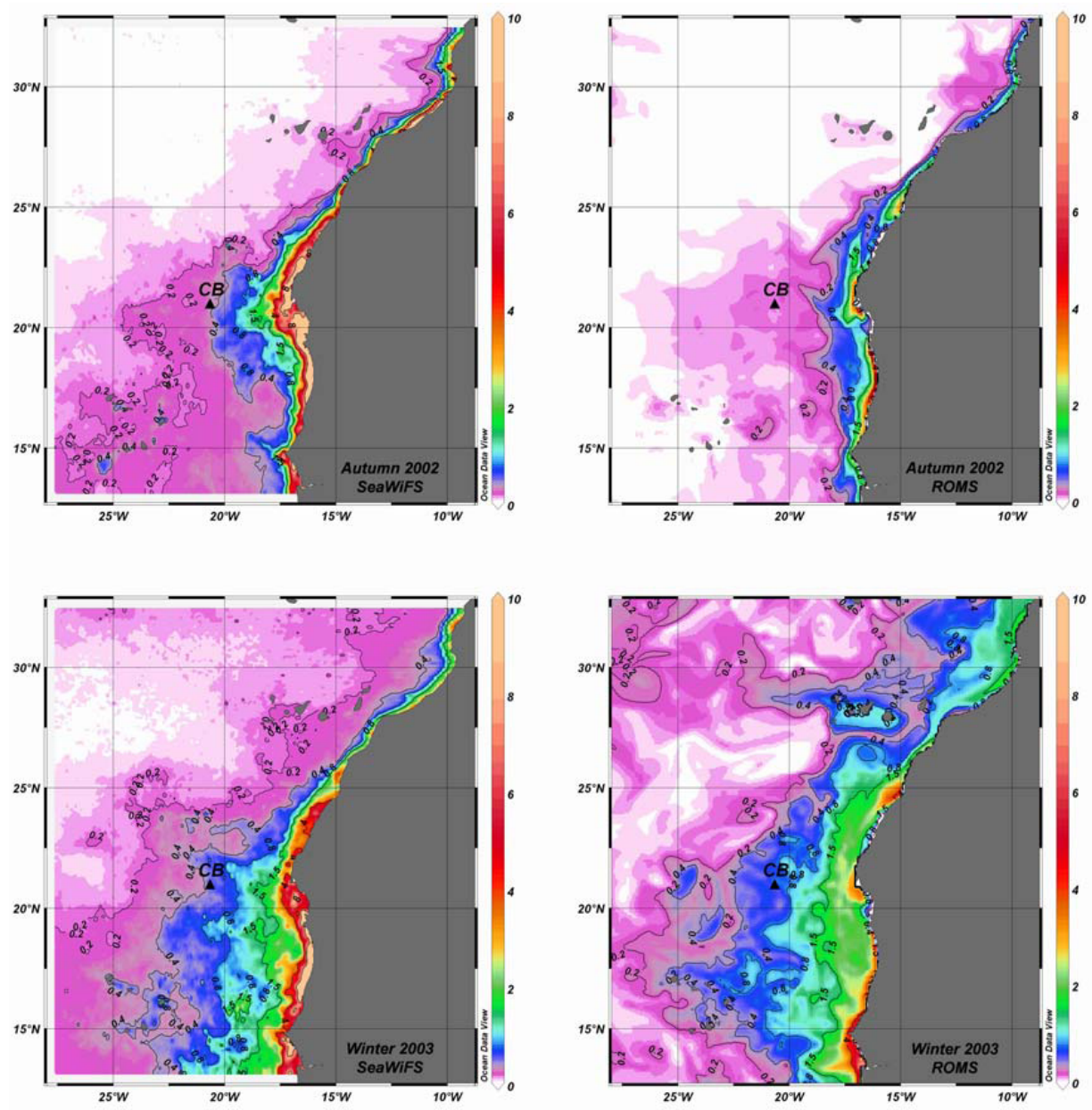

Fig. 8b. Seasonal surface chlorophyll distribution $\left(\mathrm{mg} \mathrm{m}^{-3}\right.$ ) in autumn (mid-September to mid-December) 2002 and winter (mid-December to mid-March) 2003 as inferred by SeaWiFS and simulated by the model.

In Fig. 8a and b, we compare the seasonal surface chlorophyll from the simulation to that acquired by SeaWiFS. The seasonal variation on the whole is retrieved well by the model solutions. The winter-spring bloom differentiates itself with elevated chlorophyll concentrations in these seasons over large areas of the surface ocean. However, the onshore-offshore chlorophyll gradient in the model does not appear as steep as the observed one. There also exist underestimations (mostly near the coast) and overestimations (to the north of Cape Juby, in spring and winter) of the model. The use of fine temporal resolution forcing nonetheless is proved to be worthwhile. The model performs remarkably well in winter by reproducing offshore extensions of $0.8 \mathrm{mg} \mathrm{m}^{-3}$ contour off Cape Blanc and off Cape Timiris as in the satellite data. Although below the observed concentrations, the summer filament off Cape Blanc is also seen in the model solution. At site $\mathrm{CB}$, very similar chlorophyll concentrations were produced except in autumn. In this season, the model solution $\left(0.11 \mathrm{mg} \mathrm{m}^{-3}\right)$ underestimated the observed value $\left(0.3 \mathrm{mg} \mathrm{m}^{-3}\right)$ at this station by a factor of more than two.
The seasonal variation of surface biomass is successfully mimicked in the deep water organic carbon fluxes. Figure 9 illustrates modelled fluxes against those recorded by the sediment trap at station CB in $3606 \mathrm{~m}$ depth. One has to take into consideration that temporal variability and amount of particles sinking into the ocean's floor at a particular station can only be reproduced by capturing filaments and patchiness of the flow field in the right time scales, which transport the biogeochemical properties. We believe that although slightly underestimated in winter 2003, the general pattern and carbon mass are calculated notably well by the model. It is also worth mentioning that even though particles of different origin sink in different seasons, setting seasonal sinking velocity makes prediction of deep water fluxes possible, despite the fact that the model has one phytoplankton compartment.

We must note that the settling velocity that is specified in the model is the mean rate calculated by Helmke et al. (2005) over the entire water column. Our own estimations in Table 1, which are based on the sediment trap recordings at two different water depths, are higher than this mean rate simply because the upper trap is located at $1228 \mathrm{~m}$. As the sinking 


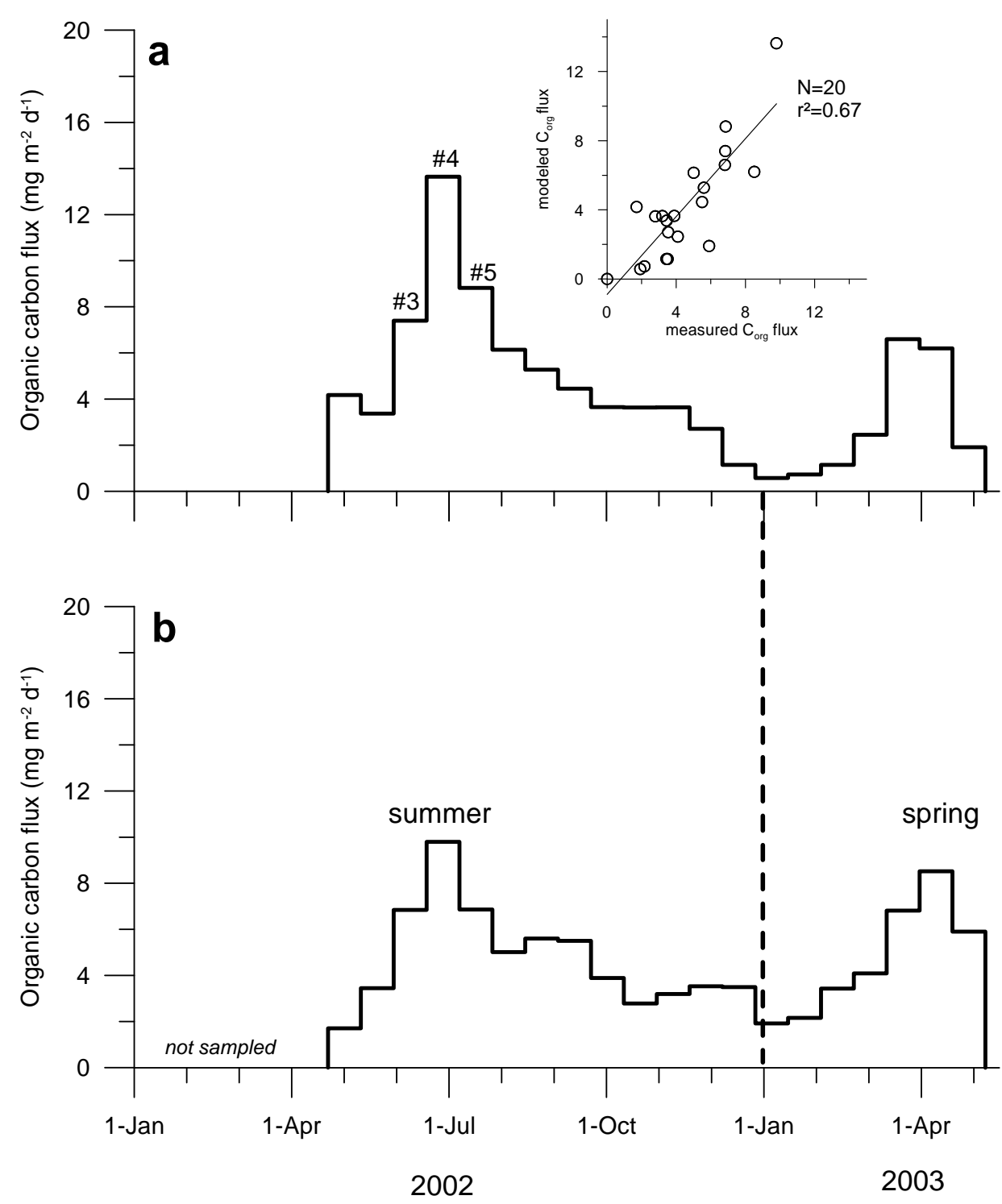

Fig. 9. Seasonal organic carbon fluxes simulated by our model (a) and measured with the deep ocean sediment trap CB-13 (3606 m, b). Sinking velocities of larger particles were set to $75 \mathrm{~m} \mathrm{~d}^{-1}$ in the model. In summer (samples \#3 to \#5), however, these values were doubled (see text and Fig. 5, Table 3). The relationship between measured and modelled organic carbon fluxes is shown as an insert in a. $\left(R^{2}=0.67\right.$, $N=20)$.

velocity increases with depth, the velocity for the entire water column must be less than the one measured in deeper layers between upper and lower traps. In fact the value given by Helmke et al. (2005) compares well to the sinking rates of alkenone associated particles shown in Table 2, that are calculated based on the time shift between maxima/minima of measured SST and alkenone-derived temperatures obtained from trap samples.
Although the mean rates over the entire water column give reasonable flux predictions in the deep sediment trap at $3606 \mathrm{~m}$ depth, the flux comparison with the upper trap do not show good correlation (data not shown) which may be due to the changing particle compositions and sinking velocities in the water column and decreased collection efficiency of shallower sediment traps (Yu et al., 2001; Scholten et al., 2001). It is therefore very unlikely that simple parameterisations with constant remineralisation and sinking rates can represent the variation in particle characteristics. 
Helmke et al. (2005) applied a linear regression model within a box area from $5^{\circ} \mathrm{N}$ to $35^{\circ} \mathrm{N}$ and $5^{\circ} \mathrm{W}$ to $35^{\circ} \mathrm{W}$ in order to estimate the total flux of organic carbon down to $1000 \mathrm{~m}$ depth and came up with values ranging between $1.1 \mathrm{Tg}$ and 2.6 Tg per year. During the period from May 2002 until April 2003, our model calculations give a total organic carbon flux of $292 \mathrm{Gg}$ down to the $3000 \mathrm{~m}$ depth contour line off the NW African upwelling region between $5^{\circ} \mathrm{N}$ and $35^{\circ} \mathrm{N}$. Since the small detritus remineralises at the surface due to slow settling it does not contribute to the calculated carbon fluxes in the depth. The estimated carbon flux is therefore solely due to large particles. Considering the fact that these particles, with a remineralisation rate of $0.06 \mathrm{~d}^{-1}$ and sinking velocity of $75 \mathrm{~m} \mathrm{~d}^{-1}$, lose approximately $80 \%$ of their mass between $1000 \mathrm{~m}$ and $3000 \mathrm{~m}$ depth, our value compares well with the estimations given by Helmke et al. (2005).

\section{Summary and conclusions}

Considering all our regional and seasonal data as well as unpublished data from experimental studies and literature values from sediment trap studies (Berelson, 2002), we have indication for higher particle sinking rates in carbonate-dominated productions systems in the equatorial Atlantic and off NW Africa (Table 3). This might reflect a major transport mode for tiny and heavy coccoliths (density=2.7-2.9 $\mathrm{g} \mathrm{cm}^{-3}$ ), being densely packed within fecal pellets which are frequently found in the material collected by sediment traps (e.g. Ploug et al., 2008b; Fischer et al., 1996b). The significance of lithogenic particles for particle sinking rates could not be clarified in this study but the high values off NW Africa remain noticeable (Table 3). This issue deserves further detailed field and laboratory investigations. A tendency to lower sinking rates was obtained in diatom-dominated production systems in the southeast Atlantic and the Southern Ocean as well as during seasonal spring blooms off Mauritania (Table 3). Our studies suggest that the type of particle carrier (i.e. densely packed coccoliths in pellets versus loosely-packed TEP-rich diatom aggregates) influences particle sinking rates and may be more important for the amount of carbon reaching the deep sea than the magnitude of primary production in the surface layer. Both during a summer coccolithophorid bloom and a fall episodic sinking event of appendicularian fecal pellets containing high amounts of coccoliths off Mauritania, sinking rates reached $566 \mathrm{~m} \mathrm{~d}^{-1}$ and $732 \pm 153 \mathrm{~m} \mathrm{~d}^{-1}$ (Ploug et al., 2008b), respectively. Such high values have not been recorded for TEP-rich diatom aggregates. However, a statistically significant relationship between total carbonate content and particle sinking rates could not be obtained and might not exist at all (De La Rocha and Passow, 2007). This could be partly due to the unknown composition of carbonate and the undefined role of dust as particle carrier. Additionally, we have to consider the shape of larger particles (size and porosity) which are not discussed here but may account for variable particle sinking rates.

We generally obtained lower particle sinking rates in the mesopelagic zone, probably reflecting the sum of aggregation and disaggregation processes in the twilight zone as well as reduced vertical sinking due to stronger horizontal and vertical currents in the surface and subsurface layer. Particle sinking rates clearly increase with depth as observed by Berelson (2002), most probably due to a loss of relatively light organic-rich materials (density around $1.06 \mathrm{~g} \mathrm{~cm}^{-3}$; Logan and Hunt, 1987) and increased scavenging of suspended fine-grained mineral particles, both of which would lead to higher particle densities. Our mean sinking rates were highest off NW Africa, decreasing southwards (Table 3). Average values of alkenone-associated particles were $9-51 \mathrm{~m} \mathrm{~d}^{-1}$ and $318 \mathrm{~m} \mathrm{~d}^{-1}$ in the upper and lower water column, respectively, thus being well within the range of other studies (e.g. Alldredge and Silver, 1988; Sawada et al., 1988) (Table 3).

Many models that try to reproduce particle fluxes and distributions in the water column apply consistent sinking rates in the order of $5-20 \mathrm{~m} \mathrm{~d}^{-1}$, which are on certain occasions capable to mimic observations in the surface or near-surface layers of the water column, e.g. particle profiles obtained by optical systems (Karakaş et al., 2006). However, their capability is limited in the deeper layers due to the small settling velocities. Particle sedimentation has an episodic nature (e.g. Fischer et al., 1996b), which is rarely captured by studies with optical systems because they provide only spot observations over a very short time period of the year. Particle cameras apparently record more the normal distribution of particles in the water column (e.g. mid-water maxima off the shelves, Karakaş et al., 2006; Nowald et al., 2006), with larger particle volumes being suspended or sinking slowly. Nevertheless, in one particle profile off NW Africa (Nowald et al., 2006), we were able to capture such an episodic sinking event occurring in spring.

We showed that it was possible to estimate organic carbon fluxes in the deep layers of the ocean to a good degree of accuracy with a simple biogeochemical model by using site specific estimations of sinking velocity and undertaking proportional changes in remineralisation rates. This requires a review of parameterisations assigned to biologically produced particles in most biogeochemical models especially when regional studies are involved. A changing seasonal sinking velocity between $75 \mathrm{~m} \mathrm{~d}^{-1}$ and $150 \mathrm{~m} \mathrm{~d}^{-1}$ showed us a satisfactory agreement of simulated values with recorded ones at the Cape Blanc site. However, the validity of mean sinking velocities and remineralisation rates prescribed in such models are limited to the depth level and possibly to the site concerned (Kriest and Oschlies, 2008). The variations in particle flux along the water column can only be represented by elaborate methods formulating alterations in 
particle composition and dynamics. For a better mathematical representation of these processes, further experimental and observational studies are also needed.

Acknowledgements. We thank the masters and crews of RV METEOR, RV Maria S. MERIAN, RV POLARSTERN and RV POSEIDON for their competent assistance during the deployments and recoveries of the mooring arrays. R. Schlitzer's constructive comments on the final draft manuscript were very helpful. Thanks are also due to N. Nowald, G. Ruhland, V. Ratmeyer and G. Meinecke (MARUM, Bremen) for their field work and support. For laboratory analysis, we are indebted to M. Klann, R. Kreutz and H. Buschhoff. We are indebted to C. Reuter for a final reading of the ms. A large part of the data were collected during the SFB 261 programme (1989-2001, G. Wefer) conducted in the Atlantic Ocean and we would like to thank the Deutsche Forschungsgemeinschaft for funding. This is publication of the the MARUM, funded by the Deutsche Forschungsgemeinschaft.

Edited by: J. Middelburg

\section{References}

Alldredge, A. and Silver, M.: Characteristics, dynamics and significance of marine snow, Prog. Oceanogr., 20, 41-82, 1988.

Alldredge, A. and Gotschalk, C. C.: Direct observations of the mass flocculation of diatom blooms: characteristics, settling velocities and formation of diatom aggregates, Deep-Sea Res. I, 36, 159171, 1989.

Angel, M. V.: Detrital organic fluxes through pelagic ecosystems, in: Flows of energy and materials in marine ecosystems, edited by: Fasham, M. J. R., 475-516, Plenum Press, New York, 1984.

Angel, M. V.: Does mesopelagic biology affect vertical flux?, in: Productivity of the Ocean: Past and Present, edited by: Berger, W. H., Smetacek, V. S., and Wefer, G., J. Wiley and Sons, Chichester, 155-173, 1989.

Armstrong, R. A., Lee, C., Hedges, J. I., et al.: A new, mechanistic model of organic carbon fluxes in the ocean based on the quantitative association of POC with ballast minerals, Deep-Sea Res. II, 49, 219-236, 2002.

Asper, V. L.: Measuring the flux and sinking speed of marine snow aggregates, Deep-Sea Res. I, 34, 1-17, 1987.

Asper, V. and Smith, W. O.: Abundance, distribution and sinking rates of aggregates in the Ross Sea, Antarctica, Deep-Sea Res. I, 50, 131-150, 2003.

Bathmann, U., Noji, T. T., Voss, M., and Peinert, R.: Copepod fecal pellets: abundance, sedimentation and content at a permanent station in the Norwegian Sea in May/June 1986, Mar. Ecol.-Prog. Ser. 38, 45-51, 1987.

Berelson, W. M.: Particle settling rates increase with depth in the ocean, Deep-Sea Res. II, 49, 237-251, 2002.

Berner, R. A. and Honjo, S.: Pelagic sedimentation of aragonite: its geochemical significance, Science, 211, 940-942, 1981.

Billet, D. S. M., Lampitt, R. S., Rice, A. L., and Mantoura, R. F. C.: Seasonal sedimenation of phytoplankton to the deep sea benthos, Nature, 302, 520-522, 1983.

Boyd, P. W. and Trull, T. W.: Understanding the export of biogenic particles in oceanic waters: Is there consensus?, Prog. Oceanogr., 72, 276-312, 2007.
Boyer, T. P., Stephens, C., Antonov, J. I., et al.: World Ocean Atlas 2001, Volume 1: Salinity, edited by: Levitus, S., NOAA Atlas NESDIS 50, US Government Printing Office, Washington DC, USA, p. 165, 2002.

Broecker, W. S.: Ocean chemistry during glacial time, Geochim. Cosmochim. Ac., 46, 1689-1705, 1982.

Bruland, K. W., Silver, M. W.: Sinking rates of fecal pellets from gelatinous zooplankon (salps, pteropods, doliolids), Mar. Biol., 63, 295-300, 1981.

Buesseler, K. O., Antia, A. N., Chen, M., et. al.: An assessment of the use of sediment traps for estimating upper ocean particle fluxes, J. Marine Syst., 65, 345-416, 2007.

Cadée, G. C., González, H., and Schnack-Schiel, S. B.: Krill diet affects faecal string settling, Polar Biol., 12, 75-80, 1992.

Cherry, R. D., Higgo, J. J. W., and Fowler, S. W.: Zooplankton fecal pellets and element residence times in the ocean, Nature, 274, 246-248, 1978.

Da Silva, A., Young, C., and Levitus, S.: Atlas of Surface Marine Data 1994, Vols. 1-5, NOAA Atlas NESDIS 6-10, US Government Printing Office, Washington DC, USA, 1994.

De La Rocha, C. L. and Passow, U.: Factors influencing the sinking of POC and the efficiency of the biological pump, Deep-Sea Res. II, 54, 639-658, 2007.

Dierks, A. R. and Asper, V. L.: In situ settling speeds of marine snow aggregates below the mixed layer: Black Sea and Gulf of Mexico, Deep-Sea Res., 44, 385-398, 1997.

Dubischar, C. D. and Bathmann, U. V.: The occurence of feacal material in relation to different pelagic systems in the Southern Ocean and its importance for vertical flux, Deep-Sea Res. II, 49, 3229-3242, 2002.

Fischer, G. and Wefer, G.: Long-term observations of particle fluxes in the Eastern Atlantic: seasonality, changes of flux with depth and comparison with the sediment record, in: The South Atlantic: Present and Past Circulation, edited by: Wefer, G., Berger, W. H., Siedler, G., and Webb, D. J., Springer, Berlin, Germany, 325-344, 1996.

Fischer, G., Donner, B., Ratmeyer, V., Davenport, R., and Wefer, G.: Distinct year-to-year flux variations off Cape Blanc during 1988-1991: relationship to $\delta^{18} \mathrm{O}$-deduced sea-surface temperatures and trade winds, J. Mar. Res., 54, 73-98, 1996a.

Fischer, G., Neuer, S., Wefer, G., and Krause, G.: Short-term sedimentation pulses recorded with a fluorescence sensor and sediment traps at $900 \mathrm{~m}$ depth in the Canary Basin, Limnol. Oceanogr., 41, 1354-1359, 1996b.

Fischer, G., Ratmeyer, V., and Wefer, G.: Organic carbon fluxes in the Atlantic and the Southern Ocean: relationship to primary production compiled from satellite radiometer data, Deep-Sea Res., 47, 1961-1997, 2000.

Fischer, G., Gersonde, R., and Wefer, G.: Organic carbon, biogenic silica and diatom fluxes in the marginal winter sea-ice zone and in the Polar Front Region: interannual variations and differences in composition, Deep-Sea Res. II, 49, 1721-1745, 2002.

Fischer, G., Neuer, S., Davenport, R., et al.: The Northwest African Margin, in: Carbon and Nutrient Fluxes in Continental Margins: A Global Synthesis, edited by: Liu, K.-K., Atkinson, L., Quinones, R., and Talaue-McManaus, L., Springer, New York, in press, 2009.

Fowler, S. W. and Small, W. F.: Sinking rates of euphausiid fecal pellets, Limnol. Oceanogr., 17, 293-296, 1972. 
Fowler, S. W. and Knauer, D. A.: The role of large particles in the transport of elements and organic components through the water column, Prog. Oceanogr., 16, 147-194, 1986.

Francois, R., Honjo, S., Krishfield, R., and Manganini, S.: Factors controlling the flux of organic carbon in the bathypelagic ocean, Global Biogeochem. Cy., 16, 1087, doi:1010.1029/2001GB001722, 2002.

Gehlen, M., Bopp, L., Emprin, N., Aumont, O., Heinze, C., and Ragueneau, O.: Reconciling surface ocean productivity, export fluxes and sediment composition in a global biogeochemical ocean model, Biogeosciences, 3, 521-537, 2006, http://www.biogeosciences.net/3/521/2006/.

Gorsky, G., Le Borgne, R., Picheral, M., and Stemmann, L.: Marine snow latitudinal distribution in the equatorial Pacific along $180^{\circ}$, J. Geophys. Res., 108, 8146, doi:10.1029/20001JC001064, 2003.

Gohin, F., Druon, J. N., and Lampert, L.: A five channel chlorophyll concentration algorithm applied to SeaWiFs data processed by SeaDAS in coastal waters, Int. J. Remote Sens., 23, 1639-1661, 2002.

Gruber, N., Frenzel, H., Doney, S. C., et al.: Eddy-resolving simulation of phytoplankton ecosystem dynamics in the California Current, Deep-Sea Res. I, 53, 1483-1516, 2006.

Hamm, C. E.: Interactive aggregation and sedimentation of diatoms and clay-sized lithogenic material, Limnol. Oceanogr., 47, 17901795, 2002.

Harding, L. W., Magnuson, A., and Mallonee, M. E.: SeaWiFS retrievals of chlorophyll in Chesapeake Bay and the mid-Atlantic bight, Estuar. Coast. Shelf S., 62, 75-94, 2005.

Helmke, P., Romero, O., and Fischer, G.: Northwest African upwelling and its effect on off-shore organic carbon export to the deep sea, Global Biogeochem. Cy., 19, GB4015, doi:10.1029/2004GB002265, 2005.

Honjo, S.: Coccoliths: production, transportation and sedimentation, Mar. Micropaleontol., 1, 65-79, 1976.

Honjo, S.: Seasonality and interaction of biogenic and lithogenic particulate flux in the Panama Basin, Science, 218, 883-884, 1982.

Intergovernmental Oceanographic Commission, International Hydrographic Organization, and British Oceanographic Data Centre (IOC, IHO, and BODC): Centenary Edition of the GEBCO Digital Atlas on Behalf of the Intergovernmental Oceanographic Commission and the International Hydrographic Organization as Part of the General Bathymetric Chart of the Oceans, CD-ROM, Liverpool, UK, 2003.

Ittekkot, V.: The abiotically driven biological pump in the ocean and short-term fluctuations in atmospheric $\mathrm{CO}_{2}$ contents, Global Planet. Change, 8, 17-25, 1993.

Jackson, G. A.: Effect of coagulation on a model planktonic food web, Deep-Sea Res. I, 48, 95-123, 2001.

Jackson, G. A.: Coagulation theory and models of oceanic plankton, in: Flocculation in Natural and Engineered Environmental Systems, edited by: Droppo, I., Leppard, G., Liss, S., and Milligan, T., CRC Press, Boca Raton, FL, 271-292, 2005.

Kanamitsu, M., Ebisuzaki, W., Woollen, J., Yang, S.-K., Hnilo, J. J., Fiorion, M., and Potter, J.: NCEP-DOE AMIP-II Reanalysis (R-2), B. Am. Meteorol. Soc., 83, 1631-1643, 2002.

Karakaş, G., Nowald, N., Blaas, M., et al.: High-resolution modelling of sediment erosion and particle transport across the NW African shelf, J. Geophys. Res., 111, C06025, doi:10.1029/2005JC003296, 2006.

Klaas, C. and Archer, D. E.:Association of sinking organic matter with various types of ballast in the deep sea: Implications for the rain ratio, Global Biogeochem. Cy., 16, 1116, doi:1110.1029/2001GB001765, 2002.

Knappertsbusch, M. and Brummer G.-J.: A sediment trap investigation of sinking coccolithophorids in the North Atlantic, Deep-Sea Res. I, 47, 1083-1109, 1995.

Kremling, K., Lentz, U., Zeitschel, B., et al.: New type of timeseries sediment trap for the reliable collection of inorganic and organic trace chemical substances, Rev. Sci. Instrum., 67, 43604363, 1996.

Kriest, I.: Different parameterizations of marine snow in a 1-Dmodel and their influence on representation of marine snow, nitrogen budget and sedimentation, Deep-Sea Res., 49, 21332162, 2002.

Kriest, I. and Oschlies, A.: On the treatment of particulate organic matter sinking in large-scale models of marine biogeochemical cycles, Biogeosciences, 5, 55-72, 2008,

http://www.biogeosciences.net/5/55/2008/.

Lampitt, R., Noji, T. T., and Bodungen, B. V.: What happens to zooplankton fecal pellets? Implications for material flux, Mar. Biol., 104, 15-23, 1990.

Lavender, S. J., Pinkerton, M. H., Froidefond, J. M., Morales, J., Aiken, J., and Moore, G. F.: SeaWiFs validation in European coastal waters using optical and bio-geochemical measurements, Int. J. Remote Sens., 25, 1481-1488, 2004.

Legendre, L. and Rivkin, R.: Fluxes of carbon in the upper ocean: regulation by food web control modes, Mar. Ecol., 242, 95-109, 2002.

Logan, B. and Hunt, J.: Advantages to microbes of growth in permeable aggregates in marine systems, Limnol. Oceanogr., 32, 1034-1048, 1987.

Marchesiello, P. and Estrade, P.: Eddy activity and mixing in upwelling systems: a comparative study of Northwest Africa and California regions, Int. J. Earth Sci., doi:10.1007/s00531-0070235-6, 2007.

Moriceau, B., Garvey, M., Ragueneau, O., and Passow, U.: Evidence for reduced biogenic silica dissolution rates in diatom aggregates, Mar. Ecol.-Prog. Ser., 333, 129-142, 2007.

Müller, P. J. and Fischer, G.: A 4-year sediment trap record of alkenones from the filamentous upwelling region off Cape Blanc, NW Africa and a comparison with distributions in underlying sediments, Deep-Sea Res. I, 48, 1877-1903, 2001.

Müller, P. J. and Fischer, G.: C37-alkenones as paleotemperature tool: fundamentals based in sediment traps and surface sediments from the South Atlantic Ocean, in: The South Atlantic in the Late Quaternary: Reconstruction of material budgets and current systems, edited by: Wefer, G., Mulitza, S., and Ratmeyer, V., Springer, Berlin, Heidelberg, New York, 167-193, 2003.

Müller, P. J. and Schneider, R.: An automated leaching method for the determination of opal in sediments and particulate matter, Deep-Sea Res. I, 40, 425-444, 1993.

Neuer, S., Ratmeyer, V., Davenport, R., et al.: Deep water particle flux in the Canary Island region: seasonal trends in relation to long-term satellite derived pigment data and lateral sources, Deep-Sea Res., 44, 1451-1466, 1997.

Neuer, S., Freudenthal, T., Davenport, R., et al.: Seasonality of sur- 
face water properties and particle flux along a productivity gradient off NW Africa, Deep-Sea Res. II, 49, 3561-3576, 2002.

Nowald, N., Karakaş, G., Ratmeyer, V., Fischer, G., Schlitzer, R., Davenport, R. A., and Wefer, G.: Distribution and transport processes of marine particulate matter off Cape Blanc (NW-Africa): results from vertical camera profiles, Ocean Sci. Discuss., 3, 903-938, 2006, http://www.ocean-sci-discuss.net/3/903/2006/

Passow, U.: Switching perspectives: Do mineral fluxes determine particulate organic fluxes or vice versa, Geochem. Geophy. Geosy., 5, Q04002, doi:04010.01029/02003GC000670, 2004.

Pilskaln, C. H. and Honjo, S.: The fecal pellet fraction of biogeochemical fluxes to the deep sea, Global Biogeochem. Cy., 1, 3148, 1987.

Pilskaln, C. H., Lehmann, C., Padaun, J. B., and Silver, M. W.: Spatial and temporal dynamics in marine aggregate abundance, sinking rate and flux: Monterey Bay, California, Deep-Sea Res. II, 45, 1803-1837, 1998.

Ploug, H. and Grossart, H. P.: Bacterial growth and grazing on diatom aggregates: Respiratory carbon turnover as a function of aggregate size and sinking velocity, Limnol. Oceanogr., 45, 1467-1475, 2000.

Ploug, H., Iversen, M., Koski, M., and Buitenhuis, E. T.: Production, oxygen respiration rates and sinking velocity of copepod fecal pellets: direct measurements of ballasting by opal and calcite, Limnol. Oceanogr., 53, 3, 469-476, 2008a.

Ploug, H., Iversen, M., and Fischer, G.: Ballast, sinking velocity, and apparent diffusivity within marine snow and zooplankton fecal pellets: Implication for substrate turnover by attached bacteria, Limnol. Oceanogr., 53(5), 1878-1886, 2008 b.

Ragueneau, O., Tréguer, P., Leynaert, A., et al.: A review of the Si cycle in the modern ocean: recent progress and missing gaps in the application of biogenic opal as a paleoproductivity proxy, Global Planet. Change , 26, 317-365, 2000.

Ragueneau, O., Schultes, S., Bidle, K., Claquin, P., and Moriceau, $\mathrm{B}$.: $\mathrm{Si}$ and $\mathrm{C}$ interactions in the world ocean: Importance of ecological processes and implications for the role of diatoms in the biological pump, Global Biogeoch. Cy., 20, GB4S02, doi:10.1029/2006GB002688, 2006.

Ratmeyer, V., Balzer, W., Bergametti, G., Chiapello, I., Fischer, G., and Wyputta, U.: Seasonal impact of mineral dust on deepocean particle flux in the eastern subtropical Atlantic Ocean, Mar. Geol., 159, 241-252, 1999.

Reynolds, R. W. and Smith, T. M.: Improved global sea surface temperature analyses using optimum interpolation, J. Climate, 7, 929-948, 1994.

Riebesell, U.: The formation of large marine snow and its sustained residence time in surface waters, Limnol. Oceanogr., 37, 63-76, 1992.
Sawada, K., Handa, N., and Nakatsuka, T.: Production and transport of long-chain alkenones and alkyl alkenoates in a sea water column in the northwestern Pacific off central Japan, Mar. Chem., 59, 219-234, 1998.

Schiebel, R.: Planktic foraminiferal sedimentation and the marine calcite budget, Global Biogeochem. Cy., 16, 1065, doi:10.1029/2001GB001459, 2002.

Scholten, J. C., Fietzke, J., and Vogler, S., et al.:Trapping efficiencies of sediment traps from the deep Eastern North Atlantic: the ${ }^{230}$ Th calibration, Deep-Sea Res. II, 48, 2383-2408, 2001.

Shanks, A. L. and Trent, J. D.: Marine snow: sinking rates and potential role in vertical flux, Deep-Sea Res. I, 27A, 137-143, 1980.

Shchepetkin, A. F. and McWilliams, J. C.: Quasi-monotone advection schemes based on explicit locally adaptive dissipiation, Mon. Weather Rev., 126, 1541-1580, 1998.

Shchepetkin, A. F. and McWilliams, J. C.: A method for computing horizontal pressure-gradient force in an oceanic model with a nonaligned vertical coordinate, J. Geophys. Res., 108(C3), 3090, doi:10.1029/2001JC001047, 2003.

Shchepetkin, A. F. and McWilliams, J. C.: The regional oceanic modeling system (ROMS): a split-explicit, free-surface, topography-following-coordinate oceanic model, Ocean Model., 9(4), 347-404, 2005.

Smetacek, V. S.: Role of sinking in diatom life-history cycles: ecological, evolutionary and geological significance, Mar. Biol., 84 239-251, 1985.

Stephens, C., Antonov, J. I., Boyer, T. P., et al.: World Ocean Atlas 2001, Volume 1: Temperature, edited by: Levitus, S., NOAA Atlas NESDIS 49, US Government Printing Office, Washington DC, USA, p. 167, 2002.

Thunell, R., Benitez-Nelson, C., Varela, R., Astor, Y., and MullerKarger, F.: Particulate organic carbon fluxes along the upwellingdominated continental margins: Rates and mechanisms, Global Biogeochem. Cy., 21, GB1022, doi:10.1029/2006GB002793, 2007.

Turner, J. T.: Zooplankton fecal pellets, marine snow and sinking phytoplankton blooms, Aquat. Microb. Ecol., 27, 57-102, 2002.

Wefer, G., Fischer, G., Fütterer, D., and Gersonde, R.: Seasonal particle flux in the Bransfield Strait, Antarctica, Deep-Sea Res., 35, 891-898, 1988.

Yu, E. F., Francois, R., Honjo, S., Fleer, A. P., Manganini, S. J., Rutgers van der Loeff, M. M., and Ittekot, V.: Trapping efficiency of bottom-tethered sediment traps estimated from the intercepted fluxes of ${ }^{230} \mathrm{Th}$ and ${ }^{231} \mathrm{~Pa}$, Deep-Sea Res. I, 48, 865-889, 2001. 